NBER WORKING PAPER SERIES

\title{
UNDERSTANDING FINANCIAL CRISES: A DEVELOPING COUNTRY PERSPECTIVE
}

Frederic S. Mishkin

Working Paper 5600

\author{
NATIONAL BUREAU OF ECONOMIC RESEARCH \\ 1050 Massachusetts Avenue \\ Cambridge, MA 02138 \\ May 1996
}

Prepared for the World Bank Annual Conference on Development Economics, April 25-26, 1996, Washington, DC. I thank Agustin Carstens and the staff at the Bank of Mexico, Terry Checki, Marilyn Skiles, and participants at seminars at the Federal Reserve Bank of New York, the International Monetary Fund, the Interamerican Development Bank and the World Bank Development Conference for their helpful comments and Martina Heyd for research assistance. The findings, interpretations and conclusions expressed in this paper are entirely those of the author. They do not necessarily represent the views of the World Bank, its Executive Directors, or the companies it represents, nor of Columbia University, the National Bureau of Economic Research, the Federal Reserve Bank of New York or the Federal Reserve System. This paper is part of NBER's research programs in Economic Fluctuations and Growth, and Monetary Economics.

(C) 1996 by Frederic S. Mishkin. All rights reserved. Short sections of text, not to exceed two paragraphs, may be quoted without explicit permission provided that full credit, including $(\mathcal{C}$ notice, is given to the source. 


\title{
UNDERSTANDING FINANCIAL CRISES: \\ A DEVELOPING COUNTRY PERSPECTIVE
}

\begin{abstract}
This paper explains the puzzle of how a developing economy can shift dramatically from a path of reasonable growth before a financial crisis, as was the case in Mexico in 1994, to a sharp decline in economic activity after a crisis occurs. It does so by outlining an asymmetric information framework for analyzing banking and financial crises in developing countries. The asymmetric information framework shows why the banking sector is so important to the economy, particularly in developing countries and provides a rationale for bank regulation and supervision. This asymmetric information framework is then used to understand why banking and financial crises occur and why they can have such a devastating effect on the economy, particularly in developing countries. The paper concludes by discussing policy implications for developing countries. An important theme is that an appropriate institutional structure is critical to preventing banking and financial crises in developing countries and to reducing their undesirable effects if they should occur.
\end{abstract}

Frederic S. Mishkin

Federal Reserve Bank of New York

33 Liberty Street

New York, NY 10045

and NBER 


\section{I.}

\section{Introduction}

Financial crises and their subset, banking crises, have become a worldwide phenomena in recent years. Not only have banking crises occurred in developed countries such as the United States, Japan, and in the Nordic countries, but they have been a feature of the recent economic scene in developing countries as well. In the case of developed countries, banking and financial crises have been costly to the economy, yet the damage that these crises seem to impose on developing countries seems to be far greater than for developed countries. Indeed an important puzzle for the study of development economics is how a developing economy can shift dramatically from a path of reasonable growth before a financial crisis, as was the case in Mexico in 1994, to a sharp decline in economic activity after a crisis occurs that is very damaging to both the economy and social fabric of the country.

This paper attempts to explain this puzzle by outlining an asymmetric information framework for analyzing banking and financial crises in developing countries. It starts by outlining the role that asymmetric information plays in a financial system and shows why the banking sector is so important to the economy, particularly in developing countries. The asymmetric information framework can then be used to derive a rationale for bank regulation and supervision, and raise some of the problems that may hinder the effective performance of bank regulatory systems. (Because my expertise lies more with the financial system in the United States, I will take examples of how the bank regulatory/supervisory system may not work as intended from the U.S. experience. However, the parallels with the problems occurring in developing countries are actually quite close.) We then can apply this asymmetric information framework to understand why banking and financial crises occur and why they can have such a devastating effect on the economy, particularly in developing countries. The paper concludes by applying the analysis earlier in the paper to discuss policy implications for developing countries. An important theme is that an appropriate institutional structure is critical to preventing banking and financial crises in developing countries and to reducing their undesirable effects if they should occur. 


\section{II. \\ The Role of Asymmetric Information \\ in the Financial System}

The financial system has an extremely important function in the economy because it enables funds to move from economic agents who lack productive investment opportunities to those who have such opportunities. Unless the financial system can do this job effectively, the economy will not function efficiently and economic growth will be severely hampered.

A crucial impediment to the efficient functioning of the financial system is asymmetric information, a situation in which one party to a financial contract has much less accurate information than the other party. For example, a borrower who takes out a loan usually has much better information about the potential returns and risk associated with the investment projects he plans to undertake than the lender does. Asymmetric information leads to two basic problems in the financial system: adverse selection and moral hazard.

\section{Adverse Selection}

Adverse selection is an asymmetric information problem that occurs before the transaction occurs when potential bad credit risks are the ones who most actively seek out a loan. Thus the parties who are the most likely to produce an undesirable (adverse) outcome are most likely to be selected. For example, those who want to take on big risks are likely to be the most eager to take out a loan because they know that they are unlikely to pay it back. Since adverse selection makes it more likely that loans might be made to bad credit risks, lenders may decide not to make any loans even though there are good credit risks in the marketplace. This outcome is a feature of the classic "lemons problem" analysis first described by Akerlof (1970). As pointed out by Myers and Majluf (1984) and Greenwald, Stiglitz and Weiss (1984), a lemons problem occurs in the debt and equity markets when lenders have trouble determining whether a lender is a good risk (he has good investment opportunities with low risk) or, alternatively, 
is a bad risk (he has poorer investment projects with high risk). In this situation, a lender will only be willing to pay a price for a security that reflects the average quality of firms issuing the securities -- a price below fair market value (the net present value of the expected income streams) for high-quality firms, but above fair market value for low-quality firms. The owners or managers of a high-quality firm that know their quality then also know that their securities are undervalued and will not want to sell them in the market. On the other hand, the firms willing to sell their securities will be low-quality firms because they know that the price of their securities is greater than their value. Since asymmetric information prevents investors from determining whether some firms are high quality, these high quality firms will issue few securities and credit markets will not work as well since many projects with a positive net present value will not be undertaken.

\section{Moral Hazard}

Moral hazard occurs after the transaction occurs because the lender is subjected to the hazard that the borrower has incentives to engage in activities that are undesirable (immoral) from the lender's point of view: i.e., activities that make it less likely that the loan will be paid back. Moral hazard occurs because the borrower has incentives to invest in projects with high risk in which the borrower does well if the project succeeds but the lender bears most of the loss if the project fails. Also the borrower has incentives to misallocate funds for his own personal use, to shirk and just not work very hard, or to undertake investment in unprofitable projects that increase his power or stature. The conflict of interest between the borrower and lender stemming from moral hazard (the agency problem) implies that many lenders will decide that they would rather not make loans, so that lending and investment will be at suboptimal levels. ${ }^{1}$

'Note that asymmetric information is not the only source of the moral hazard problem. Moral hazard can also occur because high enforcement costs might make it too costly for the lender to prevent moral hazard even when the lender is fully informed about the borrower's activities. 


\section{Why are Banks So Important?}

Asymmetric information theory explains why banks are such important players in the financial system in all countries throughout the world, and particularly so in developed countries. $^{2}$ Because an adverse selection (lemons) problem exists in securities markets in which low quality firms will be more eager to issue securities, securities markets are unlikely to play a key role in the financial system in most countries. One solution to this problem is the private production and sale of information which can reduce the degree of asymmetric information that creates the lemons problem for securities. However, the so-called free rider problem, in which people who do not pay for information can still take advantage (free ride off) of the information that other people have paid for, will result in too little private production and sale of information.

To understand the free rider problem recognize that if some investors acquire information that tells them which securities are undervalued and therefore buy their securities, other investors who have not paid for this information may be able to buy right along with the well-informed investors. If enough free-riding investors can do this, the increased demand for the undervalued securities will cause their low price to be bid up to reflect the securities' full net present value given this information. As a result of all these free riders, investors who have acquired information will no longer be able to earn the entire increase in the value of the security arising from this additional information. The weakened ability of private firms to profit from producing information will mean that less information is produced in securities markets, so that the adverse selection problem continues to be an impediment to a well-functioning securities

\footnotetext{
${ }^{2}$ Gertler (1988a) provides an excellent survey of the literature on asymmetric information and financial structure which is more general than that here because it looks at additional elements of financial structure that are explained by asymmetric information considerations. Note also that transactions cost also play a role in explaining why banks are such important players in the financial system. Banks are very well suited to reduce transactions costs because their size enables them to take advantage of economies of scale to keep transactions costs low. In addition, they develop expertise, say with computer and legal technology, to reduce transactions costs. Although transactions costs do play a role in making banks important in the financial system, asymmetric information issues are emphasized in this paper because they help explain why banks are so unique in the financial system and also help us understand phenomena such as financial crises.
} 
market.

More importantly, the free-rider problem makes it less likely that securities markets will act to reduce incentives to commit moral hazard. Monitoring and enforcement of restrictive covenants (provisions in debt contracts that restrict and specify certain activities of the borrower) are necessary to reduce moral hazard. By monitoring a borrower's activities to see whether he is complying with the restrictive covenants and enforcing the covenants if he is not, lenders can prevent borrowers from taking on risk at their expense. However, because monitoring and enforcement of restrictive covenants are costly, the free-rider problem discourages this kind of activity in securities markets. If some investors know that other securities holders are monitoring and enforcing the restrictive covenants, then they can free ride on the other securities holders' monitoring and enforcement. Once these other securities holders realize that they can do the same thing, they also may stop their monitoring and enforcement activities, with the result that not enough resources are devoted to monitoring and enforcement. The outcome is that moral hazard continues to be a severe problem for marketable securities.

The analysis above thus explains why, as Mayer (1990) points out, securities markets are frequently a relatively unimportant source of external finance to nonfinancial businesses in developed countries. Furthermore it suggests why securities markets are even less important in developing countries. Clearly, the better the quality of information about firms, the more likely it is that they can issue securities to raise funds. This implication of the theory indicates why only the largest and best known firms in developed countries issue securities. In developing countries, information about private firms is even harder to collect than in developed countries and not surprisingly, securities markets therefore play a much smaller role.

Banks play the most important role in financial systems throughout the world because they are so well suited to reducing adverse selection and moral hazard problems in financial markets. They are not as subject to the free rider problem and profit from the information they produce by making private loans that are not traded. As a result, other investors have more difficulty free riding off the financial intermediary and bidding up the loan's price which would prevent the intermediary from profiting from their information production activities. Similarly, it is hard to free ride off banks' monitoring activities when they make private loans. Banks thus receive the benefits of monitoring and so are better equipped to prevent moral hazard on the part 
of borrowers. ${ }^{3}$

Banks have particular advantages over other financial intermediaries in solving asymmetric information problems. For example, banks' advantages in information collection activities are enhanced by their ability to engage in long-term customer relationships and issue loans using lines of credit arrangements. In addition their ability to scrutinize the checking account balances of their borrowers provides them with an additional advantage in monitoring the borrowers behavior. Banks also have advantages in reducing moral hazard because, as demonstrated by Diamond (1984), they can engage in lower cost monitoring than individuals, and because, as pointed out by Stiglitz and Weiss (1983), they have advantages in preventing risk taking by borrowers since they can use the threat of cutting off lending in the future to improve borrower's behavior. Banks' natural advantages in collecting information and reducing moral hazard explain why banks have such an important role in financial markets in the developed countries. Furthermore, the greater difficulty of acquiring information on private firms in developing countries makes banks even more important in the financial systems of these countries. ${ }^{4,5}$

\footnotetext{
${ }^{3}$ Note that by making private loans, banks can not entirely eliminate the free rider problem. Knowing that a bank has made a loan to a particular company reveals information to other parties that the company is more likely to be creditworthy and will be undergoing monitoring by the bank. Thus some of the benefits of information collection produced by the bank will accrue to others. The basic point here is that by making private loans, banks have the advantage of reducing the free rider problem, but they can not eliminate it entirely.

${ }^{4}$ Rojas-Suarez and Weisbrod (1994) document that banks play a more important role in the financial systems in developing countries than they do in developed countries.

${ }^{5}$ As pointed out in Edwards and Mishkin (1995), the traditional financial intermediation role of banking has been in decline in both the United States and other developed countries because of improved information technology which makes it easier to issue securities. Although this suggests that the declining role of traditional banking which is occurring in the developed countries may eventually occur in the developing countries as well, the barriers to information collection in developing countries are so great that the dominance of banks in these countries will continue for the foreseeable future.
} 


\section{III.}

\section{Asymmetric Information and Bank Regulation}

We have seen how asymmetric information leads to adverse selection and moral hazard problems that have an important impact on the structure of the financial system. This same analysis is also very useful in understanding the common forms that bank regulation and supervision take in most countries in the world, which include: a safety net for depositors, restrictions on bank asset holdings, capital requirements, disclosure requirements, chartering, bank examinations, and prompt corrective action.

\section{Government Safety Net}

As we have seen, banks are particularly well suited to solving adverse selection and moral hazard problems because they make private loans which avoids the free rider problem. However, this solution to the free rider problem creates another asymmetric information problem because depositors lack information about the quality of these private loans, which can lead to bank panics. ${ }^{6}$ To understand the problem consider a situation in which there is no safety net for depositors. Suppose an adverse shock hits the economy, with the result that $5 \%$ of a country's banks have such large loan losses that they are insolvent. Because of asymmetric information, depositors are unable to tell whether their bank is a good bank or one of the $5 \%$ of insolvent banks. Depositors at bad and good banks recognize that they may not get back 100 cents on the dollar for their deposits and will want to withdraw them. Indeed, because banks operate on a first-come-first-served basis (the so-called sequential service constraint), depositors have a very strong incentive to show up at the bank first because if they are last on line, the bank may run out of funds and they will get nothing. Therefore uncertainty about the health of the banking system in general can lead to "runs" on banks, both good and bad, and the failure of one bank can hasten the failure of others, leading to a contagion effect. If nothing is done

${ }^{6}$ For example, see Gorton and Calomiris (1991). 
to restore the public's confidence, a bank panic can ensue in which both solvent and insolvent banks go out of business, leaving depositors with large losses.

A government safety net for depositors can short circuit runs on banks and bank panics. Deposit insurance is one form of the safety net in which depositors, sometimes with a limit to amount and sometimes not, are insured against losses due to a bank failure. With fully insured deposits, depositors don't need to run to the bank to make withdrawals -- even if they are worried about the bank's health -- because their deposits will be worth 100 cents on the dollar no matter what. Even with less than full insurance, the incentive for depositors to run to withdraw deposits when they are unsure about the bank's health is decreased.

Deposit insurance is not the only way in which governments provide a safety net to depositors. Governments often stand ready to provide support to domestic banks when they face runs even in the absence of explicit deposit insurance. This support is sometimes provided by lending from the central bank to troubled institutions, and is often referred to as the lender-oflast-resort role of the central bank. In other cases, funds are provided directly by the government to troubled institutions, or these institutions are taken over by the government and the government then guarantees that depositors will receive their money in full.

\section{Moral Hazard, Adverse Selection and the Government Safety Net}

Although a government safety net can be quite successful at protecting depositors and preventing bank panics, it is a mixed blessing. The most serious drawback of a safety net stems from moral hazard, an important feature of insurance arrangements in general because the existence of insurance provides increased incentives for taking risks that might result in an insurance payoff. Moral hazard is a prominent attribute in government arrangements to provide a safety net because depositors expect that they will not suffer losses if a bank fails. Thus they may not impose the discipline of the marketplace on banks by withdrawing deposits when they suspect that the bank is taking on too much risk. Consequently, banks that are provided with a safety net can (and do) take on greater risks than they otherwise would.

A further problem when there is a safety net arises because of adverse selection, where 
the people who are most likely to produce the adverse outcome insured against (e.g., bank failure) are those who most want to take advantage of the insurance. Because depositors have little reason to impose discipline on the bank if they know it is subject to a safety net, risk-loving entrepreneurs find the banking industry a particularly attractive one to enter---they know they will be able to engage in highly risky activities. Even worse, because depositors have so little reason to monitor the bank's activities if it has a safety net, outright crooks may also find banking an attractive industry for their activities, because it is easy for them to get away with fraud and the embezzlement of funds.

The moral hazard created by the desire to prevent bank failures has presented bank regulators with a particular quandary. Because a failure of a very large bank makes it more likely that a major systemic financial disruption will occur, bank regulators are naturally reluctant to allow a big bank to fail and create losses for its depositors. Thus, they are likely to pursue the misnamed too-big-to-fail policy in which no depositor suffers a loss. (The phrase too-big-to-fail is somewhat misleading because when the bank is closed or merged with another bank, the managers may be fired and stockholders in the bank lose their investment.) The main problem with the too-big-to-fail policy is that it increases the incentives for moral hazard, especially by large banks. Depositors at large banks know that they will not be subject to any losses, so they have no incentive to monitor the bank and prevent it from risk-taking by pulling out their deposits when it takes on too much risk. The result of the too-big-to-fail policy is that big banks take on even greater risks, thus making bank failures more likely. For example, evidence in Boyd and Gertler (1993) found that in the 1980s large banks in the U.S. did take on riskier loans than smaller banks and this led to higher loan losses for large U.S. banks.

It is also important to recognize that different systems to provide a safety net may lead to differing degrees of moral hazard incentives. A deposit insurance scheme might produce a similar amount of moral hazard to that produced by a less formal scheme in which the government clearly stands ready to support any troubled bank, because in both schemes depositors know that they will be fully protected by the government. The close equivalence of the two schemes is more likely in a banking system with a small number of large banks for which the too-big-to-fail policy is operational for most of the banking system.

However, in many situations a formal deposit insurance scheme may lead to greater 
moral-hazard risk-taking by the banking system than would occur under a less formal government safety net. Deposit insurance protects all depositors, whether the shock to the banking system is systemic (system-wide) or idiosyncratic (it only affects a single bank that is in trouble). A less formal guarantee provided by the government means that the government is less likely to respond to an idiosyncratic shock than to a systemic shock which threatens the health of the banking system. The result is that banks know that depositors may want to protect themselves and withdraw funds if they think that their bank could be brought down by an idiosyncratic shock, with the result that banks will want to reduce their risk to an idiosyncratic shock. On the other hand, with deposit insurance, the bank does not need to protect itself against idiosyncratic shocks and so has greater incentives to take on more risk. This phenomena was operational in the United States, particularly in the S\&L industry where many small institutions, knowing that deposit insurance protected their depositors under all conditions, were able to pursue very rapid growth which exposed them to idiosyncratic risks which eventually brought them down and imposed large losses on the American taxpayer.

\section{Restrictions on Asset Holdings and Bank Capital Requirements}

As we have seen, the moral hazard created by a government safety net encourages too much risk-taking on the part of banks. Bank regulations that restrict asset holdings and bank capital requirements are directed at preventing this moral hazard which can cost taxpayers dearly.

Even in the absence of a government safety net, banks still have the moral hazard incentive to take on too much risk. Risky assets may provide the bank with higher earnings when they pay off; but if they do not pay off and the bank fails, the depositor is left holding the bag. If depositors were able to easily monitor the bank by acquiring information on its risktaking activities, they would immediately withdraw their deposits if the bank was taking on too much risk. Then to prevent such a loss of deposits, the bank would be more likely to reduce its risk-taking activities. Unfortunately, acquiring the information on a bank's balance-sheet and off-balance-sheet activities that indicates how much risk the bank is taking is a difficult task. 
Thus, most depositors are incapable of imposing discipline on the banks which might prevent banks from engaging in risky activities. A strong rationale for government regulation to reduce risk-taking on the part of banks therefore exists even in the absence of a government safety net.

Bank regulations that restrict banks from holding risky assets such as common stock are a direct means of making banks avoid too much risk. Bank regulations also promote diversification which reduces risk by limiting the amount of loans in particular categories or to individual borrowers. Requirements that banks have sufficient bank capital are another way to change the bank's incentives to take on less risk. When a bank is forced to have a large amount of equity capital, it has more to lose if it fails and is thus less likely to engage in moral hazard and will pursue less risky activities. Another way of stating the purpose of capital requirements is that they help to align the banks' incentives more with those of the regulator. In addition, capital requirements can be tied to the amount of risk taking the bank is pursuing, as with the Basle agreements, in effect charging the bank a higher insurance premium when it takes on more risk, thereby discouraging risk taking.

\section{Chartering and Examination}

Because banks can be used by risk-taking individuals or even by crooks who intend to engage in highly speculative activities, such undesirable people are likely to want to run a bank. Chartering of banks is one method for preventing this adverse selection problem; through chartering, proposals for new banks are screened to prevent undesirable people from controlling them.

Regular bank examinations, which allow regulators to monitor whether the bank is complying with capital requirements and restrictions on asset holdings, also function to limit moral hazard. In addition, bank examiners can assess whether the bank has the proper management controls in place to prevent fraud or excessive risk taking. With this information about a bank's activities, bank examiners can enforce capital requirements and force a bank to revise its management practices if they are jeopardizing the safety and soundness of the bank. Actions taken by examiners to reduce moral hazard by preventing banks from taking on too 
much risk further help to reduce the adverse selection problem because, with less of an opportunity for risk-taking, risk-loving entrepreneurs will be less likely to be attracted to the banking industry.

\section{Disclosure Requirements}

The free-rider problem described earlier indicates that individual depositors and other bank creditors will not have enough incentive to produce private information about the quality of a bank's assets. In order to ensure that there is better information for depositors and the marketplace, regulators can require that banks adhere to certain standard accounting principles and disclose a wide range of information that helps the market assess the quality of a bank's portfolio and the amount of the bank's exposure to risk. More public information about the risks incurred by banks and the quality of their portfolio can better enable stockholders, creditors and depositors to evaluate and monitor banks, and so act as a deterrent to excessive risk-taking. This view is consistent with a recent discussion paper issued by the Euro-currency Standing Committee of the G-10 Central Banks (1994), which recommends that estimates of financial risk generated by firms' own internal risk management systems be adapted for public disclosure purposes. ${ }^{7}$ Such information would supplement disclosures based on traditional accounting conventions by providing information about risk exposures and risk management that is not normally included in conventional balance sheet and income-statement reports.

\section{Prompt Corrective Action}

Bank regulation can reduce moral hazard and adverse selection problems in the banking system only if regulators pursue prompt corrective action if banks are not complying with the regulatory requirements. This means that bank supervisors must enforce regulations in a consistent fashion and must not pursue regulatory forbearance, that is, allow banks to keep on

\footnotetext{
${ }^{7}$ See also the Federal Reserve Bank of New York (1994), which is a companion piece to the Eurocurrency Standing Committee's report.
} 
operating as usual despite noncompliance with regulations because it is hoped that the bank's problem will go away with time. Even if the bank's noncompliance is likely to disappear over time, by allowing the bank to keep operating as usual, an additional moral hazard problem for the banking system is created. Other banks, seeing that regulatory forbearance is occurring, will recognize that they can take greater risks which might lead to noncompliance and yet they are less likely to be punished for it. The result is that their incentives to engage in moral hazard will have increased. Another way of thinking about this is that even if regulatory forbearance seems to be an appropriate strategy at the time, it creates incentives in the future that may lead to undesirable behavior for the banking system. ${ }^{8}$

It is particularly important that regulatory forbearance not be pursued with regard to bank capital requirements. If a bank has too little capital, its incentives to engage in moral hazard and take big risk increases dramatically. The most extreme case is when the institution is economically insolvent and its owners have almost nothing to lose by taking on great risk and "betting the bank": If the bank gets lucky and its risky investments pay off, then the bank gets out of insolvency. Unfortunately, if, as is likely, the risky investments don't pay off, the bank's losses will mount and the government will be left holding the bag.

\section{Why the Regulatory Process Might Not Work as Intended?}

In order to act in the public interest and lower costs to the deposit insurance agency, we have seen that regulators have several tasks. They must set tight restrictions on holding assets that are too risky, must impose adequate capital requirements, and must not engage in regulatory forbearance, particularly that which allows insolvent institutions to continue to operate. However, this is not what always occurs in practice.

There are two reasons why the regulatory process might not work as intended. The first is that regulators and bank managers may not have sufficient resources or knowledge to do their

\footnotetext{
${ }^{8}$ The problem here is similar to the time inconsistency problem of optimal policy discussed in the macroeconomics literature (see Kydland and Prescott (1977)). Although a policy might be optimal ex post, it will result in a suboptimal outcome because economic agents are forward looking.
} 
job properly. An example of this occurred in the United States and helped lead a regulatory breakdown in the savings and loan (S\&L)industry in the 1980s. One aspect of the deregulation wave of the early 1980s was the passage of legislation in 1980 and 1982 that deregulated the S\&L industry and opened up many lines of business for these institutions. These thrift institutions, which had been restricted almost entirely to making loans for home mortgages, now were allowed to have up to $40 \%$ of their assets in commercial real estate loans, up to $30 \%$ in consumer lending, and up to $10 \%$ in commercial loans and leases. In the wake of this legislation, savings and loans regulators allowed up to $10 \%$ of assets to be in junk bonds or in direct investments (common stocks, real estate, service corporations, and operating subsidiaries).

Three problems arose from these expanded powers for S\&Ls. First many S\&L managers did not have the required expertise to manage risk appropriately in these new lines of business. Second, the new powers meant that there was a rapid growth in new lending, particularly to the real estate sector. Even if the required expertise was available initially, rapid credit growth may outstrip the available information resources of the banking institution, resulting in excessive risk taking. Third, these new powers of the S\&Ls and lending boom meant that their activities were expanding in scope and were becoming more complicated, requiring an expansion of regulatory resources to appropriately monitor these activities. Unfortunately, regulators of the S\&Ls at the Federal Savings and Loan Insurance Corporation (FSLIC) neither had the expertise nor were provided with additional resources which would have enabled them to sufficiently monitor these new activities. Given the lack of expertise in both the S\&L industry and the weakening of the regulatory apparatus, it is no surprise that S\&Ls took on excessive risks, which helped lead to massive losses to the American taxpayer.

The scenario described above in the United States was not unique and has occurred in other developed countries. A striking example occurred in the Nordic countries -- Norway, Sweden and Finland -- when they deregulated their financial markets in the early 1980 s. $^{9}$ The lack of expertise in both the banking industry and its regulators to keep risk taking in check, particularly when bank credit growth was very high as a result of a lending boom, resulted in massive losses to banks loan portfolios when real estate prices collapsed in the late 1980s. The

\footnotetext{
${ }^{9}$ See Drees and Pazarbasioglu (1995).
} 
result was a government bailout of the banking industry in those countries which was similar in scale relative to GDP to that which occurred in the United States. The Japanese banking crisis that has been unfolding in recent years also shares common elements with the episode in the Nordic countries. Deregulation of the financial system in Japan in the 1980s was followed by increased Japanese bank lending, especially to the real estate sector, which resulted in huge loan losses when the real estate sector collapsed.

The second reason why regulators may not do their job properly is explained by understanding that the relationship between voters-taxpayers and the regulators and politicians creates a particular type of moral hazard problem, the principal-agent problem. The principalagent problem occurs when the agent has different incentives than the person he works for (the principal) and so acts in his own interest rather than in the interest of his employer. Regulators and politicians are ultimately agents for voters-taxpayers (principals) because in the final analysis taxpayers bear the cost of any losses when the safety net is invoked. The principal-agent problem occurs because the agent (a politician or regulator) may not have the same incentives to minimize costs to the economy as the principal (the taxpayer). Indeed, the principal-agent problem stems from asymmetric information because the principal does not have sufficient information about what the agent is doing to make sure that the agent is operating in the principal's interest.

A classic example of this principal-agent problem occurred in the United States during the savings and loan debacle of the 1980s. By the late 1970s, many savings and loans in the United States were actually insolvent because most of their assets were tied up in fixed-rate longterm mortgages whose rates had been fixed at a time when interest rates were quite low. When interest rates rose in the 1970 s and early 1980s, the cost of funds for these institutions rose dramatically, while their fixed-rate mortgages did not produce higher income. The result was that the economic net worth of the S\&Ls plunged dramatically. In addition, the 1981-1982 recession and the collapse in the prices of energy and farm products hit the economies of certain parts of the country such as Texas very hard, with the result that there were defaults on many S\&Ls' loans. Losses for savings and loan institutions mounted to $\$ 10$ billion in 1981--1982, and by some estimates over half of the S\&Ls in the United States had a negative net worth and were thus insolvent by the end of 1982 . 
As our analysis earlier indicates, the incentives to engage in risk-taking moral hazard increased dramatically for these insolvent institutions because they now had little to lose and a lot to gain by taking on excessive risks. Clearly, it was essential that prompt corrective action be enforced and these institutions be closed down. Instead, S\&L regulators loosened capital requirements and restrictions on risky asset holdings and pursued regulatory forbearance. One important incentive for regulators that explains this phenomenon is their desire to escape blame for poor performance by their agency. By loosening capital requirements and pursuing regulatory forbearance, regulators hide the problem of an insolvent bank and hope that the situation will improve. Such behavior on the part of regulators is described by Edward Kane of Ohio State University as "bureaucratic gambling." ${ }^{10}$

Another important incentive for regulators is that they want to protect their careers by acceding to pressures from the people who most influence their careers. These people are not the taxpayers but the politicians who try to keep regulators from imposing tough regulations on institutions that are major campaign contributors. Members of Congress have often lobbied regulators to ease up on a particular S\&L that contributed large sums to their campaigns.

In addition, both the U.S. Congress and the presidential administration promoted banking legislation in 1980 and 1982 that made it easier for savings and loans to engage in risk-taking activities. After the legislation passed, the need for monitoring the S\&L industry increased because of the expansion of permissible activities. The $S \& L$ regulatory agencies needed more resources to carry out their monitoring activities properly, but Congress (successfully lobbied by the S\&L industry) was unwilling to allocate the necessary funds. As a result, the S\&L regulatory agencies became so short on personnel that they actually had to cut back on their onsite examinations, just when they were most needed. In the period from January 1984 until July 1986, for example, several hundred S\&Ls were not even examined once. Even worse, spurred on by the intense lobbying efforts of the S\&L industry, Congress was only willing to pass legislation in 1987 (the Competitive Banking Equality Act) which provided a totally inadequate amount ( $\$ 15$ billion) to close down the insolvent S\&Ls. Only when the crisis had reached massive proportions requiring a bailout on the order of $\$ 150$ billion in present value terms did

\footnotetext{
${ }^{10}$ See Edward Kane (1989).
} 
Congress pass in 1991 the Federal Deposit Insurance Corporation Act (FDICIA) which provided the necessary funds to clean up the S\&L mess and which tightened up the bank regulatory process.

\title{
IV.
}

\section{A Theory of Banking and Financial Crises:}

\section{A Developing Country Perspective}

In recent years, the asymmetric information analysis which we have been applying to understanding the structure of the financial system and the rationale for bank regulation has also been used to develop a theory of banking and financial crises. ${ }^{11}$ This theory has been created to explain banking and financial crises mostly in the developed country context, particularly for the United States. However, the institutional framework in the U.S. has been quite different from that existing currently in many developing countries, and thus, as we shall see, this requires some modification to the theory in order to understand the banking and financial crises phenomena in developing countries.

\section{Defining A Financial Crisis}

Asymmetric information theory provides the following definition of what a financial crisis is.

\begin{abstract}
A financial crisis is a nonlinear disruption to financial markets in which adverse selection and moral hazard problems become much worse, so that financial markets are unable to efficiently channel funds to those who have the most productive investment opportunities.
\end{abstract}

${ }^{11}$ For example, see Bernanke (1983), Calomiris and Gorton (1991) and Mishkin (1991, 1994). 
A financial crisis thus results in the inability of financial markets to function efficiently, which leads to a sharp contraction in economic activity.

\section{Factors Leading to Banking and Financial Crises}

In order to understand why banking and financial crises occur and more specifically how they lead to contractions in economic activity, we need to outline what factors lead to banking and financial crises. There are four categories of factors that promote financial crises: increases in interest rates, increases in uncertainty, asset market effects on balance sheets, and bank panics.

Increases in Interest Rates. As demonstrated by Stiglitz and Weiss (1981), asymmetric information and the resulting adverse selection problem can lead to credit rationing in which some borrowers are denied loans even when they are willing to pay a higher interest rate. This occurs because individuals and firms with the riskiest investment projects are exactly those who are willing to pay the highest interest rates since if the high-risk investment succeeds, they will be the main beneficiaries. Thus a higher interest rate leads to even greater adverse selection; that is, it increases the likelihood that the lender is lending to a bad credit risk. If the lender cannot discriminate among the borrowers with the riskier investment projects, it may want to cut down the number of loans it makes, which causes the supply of loans to decrease with the higher interest rate rather than increase. Thus, even if there is an excess demand for loans, a higher interest rate will not be able to equilibrate the market because additional increases in the interest rate will only decrease the supply of loans and make the excess demand for loans increase even further. ${ }^{12}$

\footnotetext{
${ }^{12}$ Jaffee and Russell (1976) have demonstrated a second type of credit rationing in which lenders make loans but limit their size to less than the borrower may want. This occurs because the larger the loan, the greater are moral hazard incentives for the borrower to engage in activities that make it less likely that the loan will be repaid.
} 
The theory behind credit rationing can be used to show that increases in interest rates can be one factor that help precipitate a financial crisis. If market interest rates are driven up sufficiently, there is a higher probability that lenders will lend to bad credit risks, those with the riskiest investment projects, because good credit risks are less likely to want to borrow while bad credit risks are still willing to borrow. Because of the resulting increase in adverse selection, lenders will want to make fewer loans, possibly leading to a steep decline in lending which will lead to a substantial decline in investment and aggregate economic activity. Indeed, as Mankiw (1986) has demonstrated, a small rise in the riskless interest rate can sometimes lead to a very large decrease in lending and even a possible collapse in the loan market.

Increases in Uncertainty. A dramatic increase in uncertainty in financial markets, due perhaps to the failure of a prominent financial or non-financial institution, a recession, political instability or a stock market crash make it harder for lenders to screen out good from bad credit risks. The increase in uncertainty therefore makes information in the financial markets even more asymmetric and makes the adverse selection problem worse. The resulting inability of lenders to solve the adverse selection problem renders them less willing to lend, leading to a decline in lending, investment, and aggregate activity.

Asset Market Effects on Balance Sheets. The state of the balance sheet of both nonfinancial firms and banks has important implications for the severity of asymmetric information problems in the financial system. Deterioration of balance sheets worsens both adverse selection and moral hazard problems in financial markets and if this deterioration is dramatic enough, it is a major factor leading to banking and financial crises.

An important way that financial markets can solve asymmetric information problems is with the use of collateral. Collateral reduces the consequences of adverse selection or moral hazard because it reduces the lender's losses in the case of a default. If a borrower defaults on a loan, the lender can take title to the collateral and sell it to make up for the losses on the loan. Thus, if the collateral is of good enough quality, the fact that there is asymmetric information between borrower and lender is no longer as important since the loss incurred by the lender if 
the loan defaults is substantially reduced.

Net worth performs a similar role to collateral. If a firm has high net worth, even if it defaults on its debt payments as a result of poor investments, the lender can take title to the firm's net worth, sell it off, and use the proceeds to recoup some of the losses from the loan. (Note that in a multi-period context, Gertler (1988b) shows that the concept of a borrower's net worth can be broadened to include the discounted value of future profits which is reflected in the market value of the borrowing firm.) In addition, the more net worth a firm has in the first place, the less likely it is to default because the firm has a cushion of assets that it can use to pay off its loans. High net worth also directly decreases the incentives for borrowers to commit moral hazard because they now have more at stake, and thus more to lose, if they default on their loans. Hence, when firms seeking credit have high net worth, the consequences of adverse selection and moral hazard are less important and lenders will be more willing to make loans.

Stock market crashes have an important role to play in promoting banking and financial crises through the net worth effects on adverse selection and moral hazard problems described above. As emphasized by Greenwald and Stiglitz (1988), Bernanke and Gertler (1989), and Calomiris and Hubbard (1990), a sharp decline in the stock market, as in a stock market crash, can increase adverse selection and moral hazard problems in financial markets because it leads to a large decline in the market value of firms' net worth. (Note that this decline in asset values could occur either because of expectations of lower future income streams from these assets or because of a rise in market interest rates which lowers the present discounted value of future income streams.) The decline in net worth as a result of a stock market decline makes lenders less willing to lend because, as we have seen, the net worth of firms has a similar role to collateral, and when the value of collateral declines, it provides less protection to lenders so that losses from loans are likely to be more severe. In addition, the decline in corporate net worth as a result of a stock market decline increases moral hazard incentives for borrowing firms to make risky investments because these firms now have less to lose if their investments go sour. Because borrowers have increased incentives to engage in moral hazard and because lenders are now less protected against the consequences of adverse selection, the stock market decline leads to decreased lending and a decline economic activity. 
Although we have seen that increases in interest rates have a direct effect on increasing adverse selection problems, debt markets also play a role in promoting a financial crisis through both firms' and households' balance sheets. As pointed out in Bernanke and Gertler's (1995) excellent survey of the credit view, an important transmission mechanism of monetary policy, a rise in interest rates and therefore in households' and firms' interest payments decreases firms' cash flow, which causes a deterioration in their balance sheets. ${ }^{13}$ As a result, adverse selection and moral hazard problems become more severe for potential lenders to these firms and households, leading to a decline in lending and economic activity. There is thus an additional reason why sharp increases in interest rates can be an important factor leading to financial crises.

In economies in which inflation has been moderate, which characterizes most developed countries, many debt contracts are typically of fairly long duration. In this institutional environment, an unanticipated decline in inflation leads to a decrease in the net worth of firms. Debt contracts with long duration have interest payments fixed in nominal terms for a substantial period of time, with the fixed interest rate allowing for expected inflation. When inflation turns out to be less than anticipated, which can occur either because of an unanticipated disinflation as occurred in the United States in the early 1980s or by an outright deflation as frequently occurred before World War II in the U.S., the value of firms' liabilities in real terms rises so that there is an increased burden of the debt, but there is no corresponding rise in the real value of firms' assets. The result is that net worth in real terms declines. A sharp unanticipated disinflation or deflation, therefore causes a substantial decline in real net worth and an increase in adverse selection and moral hazard problems facing lenders. The resulting increase in adverse selection and moral hazard problems (of the same type that were discussed in assessing the effect of net worth declines earlier) will thus also work to cause a decline in investment and economic activity.

In contrast to the developed countries, many developing countries have experienced very high and variable inflation rates, with the result that debt contracts are of very short duration. For example, in Mexico, almost all bank lending is with variable rate contracts which are

\footnotetext{
${ }^{13}$ Additional recent surveys which discuss this monetary transmission channel are Hubbard (1995), Cecchetti (1995) and Mishkin (1996).
} 
usually adjusted on a monthly basis. With this institutional framework, a decline in unanticipated inflation does not have the unfavorable direct effect on firms' balance sheets that it has in developed countries, because the short duration of the debt contracts means that there is almost no change in the burden of the debt when inflation falls because the terms of the debt contract are continually changed to reflect expectations of inflation. Thus one mechanism that has played a role in low inflation countries to promote financial crises has no role in developing countries that have experienced high and variable inflation. ${ }^{14}$

On the other hand, there is another factor which affects balance sheets that can be extremely important in precipitating a financial crisis in developing countries that is not operational in most developed countries: unanticipated exchange rate depreciation or devaluation. Because of uncertainty about the future value of the domestic currency, many nonfinancial firms, banks and govemments in developing countries find it much easier to issue debt if it is denominated in foreign currencies. ${ }^{15}$ This was a prominent feature of the institutional structure in Chilean financial markets before the financial crisis in 1982 and in Mexico in 1994. This leads to a factor that can lead to a financial crisis in developing countries which operates in a similar fashion to an unanticipated decline in inflation in developed countries. With debt contracts denominated in foreign currency, when there is an unanticipated depreciation or devaluation of the domestic currency, the debt burden of domestic firms increases. Since assets are typically denominated in domestic currency, there is a resulting deterioration in firms' balance sheets and the decline in net worth, which then increases adverse selection and moral hazard problems along the lines described above. The increase in asymmetric information problems leads to a decline in investment and economic activity.

\footnotetext{
${ }^{14}$ However, a decline in unanticipated inflation during periods when an anti-inflation program is in progress in developing countries has often been associated with very high real interest rates. Thus an unanticipated decline in inflation can negatively affect firms' balance sheets in developing countries through the cash flow mechanism discussed above.

${ }^{15}$ Note that in some developed countries, a substantial amount of debt is denominated in foreign currency. This was the case for the Nordic countries and helped exacerbate their banking crises in the late 1980s and early 1990s. As this example makes clear, the distinction between developed and developing countries in terms of the institutional structure of their financial system is not clear cut. Some developed countries have attributes of their financial structure that are typical of developing countries and vice versa.
} 
Bank Panics. As we have seen, banks have a very important role in financial markets since they are well suited to engage in information-producing activities that facilitate productive investment for the economy. Thus the simultaneous failure of many banks reduces the amount of financial intermediation undertaken by banks, and will thus lead to a decline in investment and aggregate economic activity. Indeed, even if the banks do not fail, but instead just suffer a substantial contraction in their capital, bank lending will decline, thereby leading to a contraction in economic activity. Research in the United States suggests that this mechanism was operational during the early 1990s in the United States, and that the capital crunch led to the headwinds mentioned by Alan Greenspan that hindered growth in the U.S. economy at that time. ${ }^{16}$

As mentioned earlier, the source of a bank panic is again asymmetric information. In a panic, depositors, fearing the safety of their deposits and not knowing the quality of the banks' loan portfolios, withdraw them from the banking system, causing a contraction in loans and a multiple contraction in deposits, which then causes banks to fail. Asymmetric information is critical to this process because depositors rush to make withdrawals from solvent as well as insolvent banks since they cannot distinguish between them.

This process of runs on banks and bank panics is clearly more likely to occur when banks' balance sheets are in a weakened state, making it more likely that the bank is insolvent. Weak bank balance sheets can occur because, for reasons described earlier, the supervisory/regulatory structure has not worked well enough to restrain excessive risk-taking on the part of banks. In addition, banks can be buffeted by shocks that cause a rapid deterioration in their balance sheets.

Negative shocks to banks' balance sheets can take several forms. We have already seen how increases in interest rates, stock market crashes, an unanticipated decline in inflation (for developed countries), or an unanticipated depreciation or devaluation (for developing countries with debt denominated in foreign currencies), can cause a deterioration in nonfinancial firms'

${ }^{16}$ For example, see Bernanke and Lown (1991), Berger and Udell (1994), Hancock, Laing and Wilcox (1995) and Peek and Rosengren (1995) and the symposium published in the Federal Reserve Bank of New York Quarterly Review in the Spring of 1993, Federal Reserve Bank of New York (1993). 
balance sheets that makes it less likely that they can pay their loans back. Thus these factors can help precipitate sharp increases in loan losses which increase the probability of bank insolvency.

Banks in developing countries face additional potential shocks that can make a banking crisis more likely. First is that developing countries which are often primary goods producers are often subject to large terms of trade shocks that can devastate banks' balance sheets whose assets are composed primarily of loans to domestic firms. The lack of diversification outside their country can thus be a severe problem for banks in developing countries that is not present for many banking institutions in developed countries which do have the ability to diversify across countries. ${ }^{17}$

Also banks in many developing countries raise funds with liabilities that are denominated in foreign currencies. A depreciation or devaluation of the domestic currency can thus lead to increased indebtedness, while the value of the banks' assets do not rise. The resulting deterioration in banks' equity capital then increase the possibility of bank failures and bank panics. Even if the exchange rate depreciation does not lead to bank failures directly, it can lead to substantial declines in bank lending because the resulting drop in bank capital results in a failure of banks to meet capital standards, such as the Basle requirements. The decline in bank capital then requires banks to shrink their lending until they can raise new capital to meet the capital standards.

\section{V. \\ Applying the Theory of Financial Crises to Past Episodes}

The theory of banking and financial crises laid out in this section can be verified by

\footnotetext{
${ }^{17}$ However, even in developed countries, the institutional structure of the banking system may prevent diversification, resulting in banks which are subject to terms of trade shocks. For example, because banks in Texas in the early 1980s did not diversify outside their region, they were devastated by the sharp decline in oil prices that occurred in 1986. Indeed, this terms of trade shock to the Texas economy which was very concentrated in the energy sector resulted in the failure of the largest banking institutions in that state.
} 
seeing if it can explain the sequence of events that have occurred during banking and financial crises in the past. As the discussion of the theory indicates, the institutional framework in developed versus developing countries is sufficiently different that we would expect a somewhat different sequence of events for these different types of countries. We first can look at how well the theory explains the facts for a developed country like the United States in the nineteenth and early twentieth centuries and then go on to see how well it does for a recent developing country experience, that of Mexico in 1994 and 1995.

\section{United States, 19th and early 20th centuries.}

The United States has a rich history of banking and financial crises, with these crises occurring every twenty years or so in the nineteenth and early twentieth centuries. Figure 1 provides a diagrammatic exposition of the sequence of events that occurred in U.S. banking and financial crises, which are outlined below.

As documented in Mishkin (1991) and in Figure 1, most financial crises in the U.S. indeed began with a sharp rise in interest rates (frequently resulting from a rise in interest rates abroad, particularly in the London market), a stock market crash and an increase in uncertainty arising after the start of a recession and from a failure of major financial or non-financial firms (the Ohio Life Insurance \& Trust Co. in 1857, the Northem Pacific Railroad and Jay Cooke \& Co. in 1873 , Grant \& Ward in 1884 , the National Cordage Co. in 1893, the Knickerbocker Trust Company in 1907, and the Bank of United States in 1930.) During these crises the increase in uncertainty, the rise in interest rates and the stock market crash increased the severity of adverse selection problems in credit markets, while the decline in net worth stemming from the stock market crash also increased moral hazard problems. The increase in adverse selection and moral hazard problems made it less attractive for lenders to lend and led to a decline in investment and aggregate economic activity. ${ }^{18}$

\footnotetext{
${ }^{18}$ As described in Mishkin (1991) an important signal of increased asymmetric information problems in financial markets is an increased spread between interest rates on low versus high quality bonds. As the theory predicts, the spread between interest rates on low and high-quality bonds rose when these events occurred, indicating that adverse selection and moral hazard problems were indeed worsening.
} 


\section{The Sequence of Events in U.S. Financial Crises of the 19th and Early 20th Centuries}

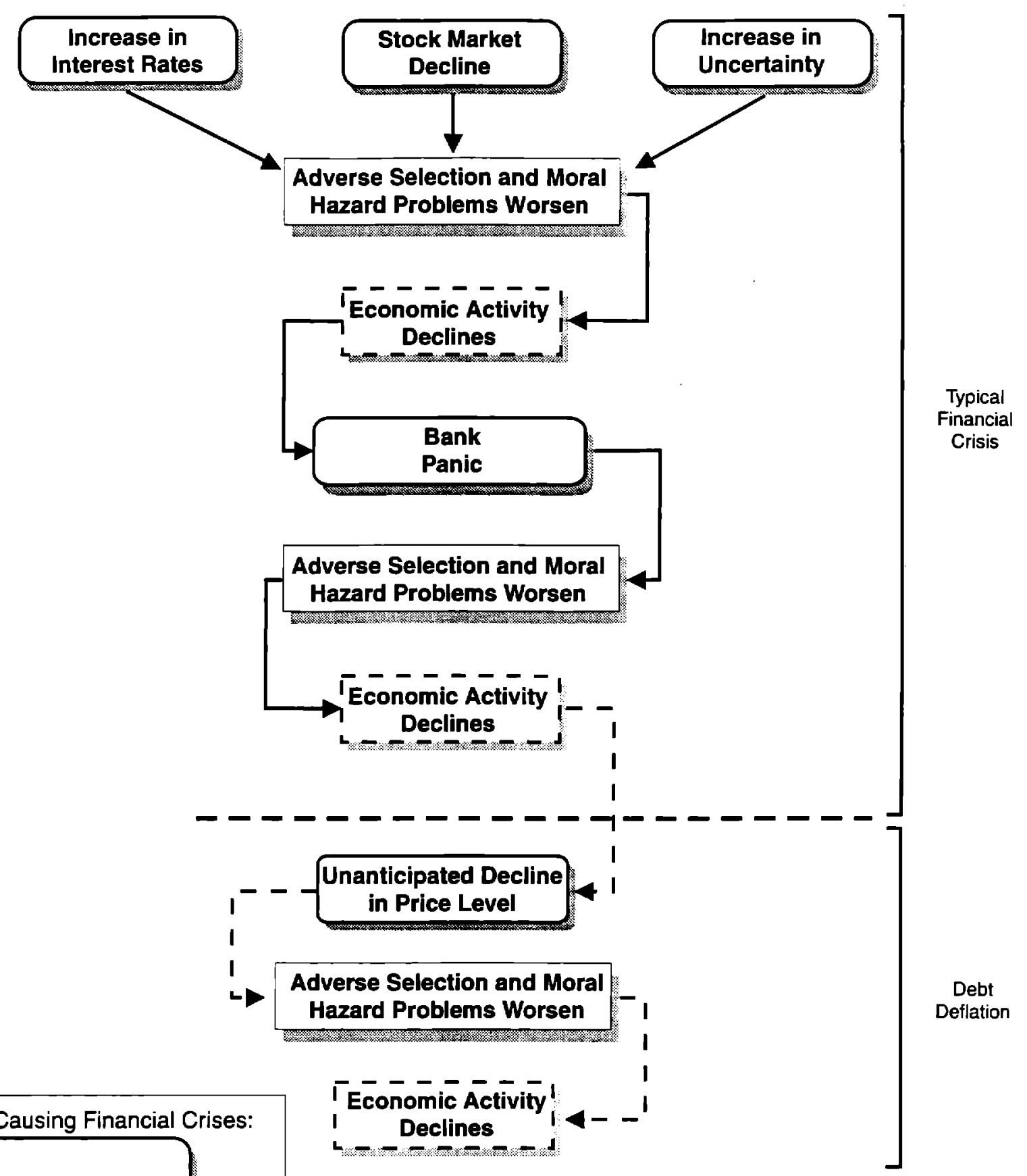

Consequences of Changes in Factors:

Adverse Selection and Moral Hazard Problems Worsen

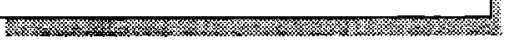

I Economic Activity |
Declines 
Because of the worsening business conditions and uncertainty about their bank's health, depositors now began to withdraw their funds from banks because they worried that the banks might become insolvent. The resulting bank panic, in which the number of banks declined, raised interest rates even further and decreased the amount of financial intermediation by banks. With the bank panic, the spread between interest rates on low and high quality bonds jumped even further, indicating a further worsening of the problems created by adverse selection and moral hazard, which, in turn, led to further economic contraction.

In many of the episodes, such as the panics of $1857,1884,1890,1893$, and 1907, there now would be a sorting out of insolvent firms from healthy firms by bankruptcy proceedings and the same process would occur for banks, often with the help of public and private authorities. Once this sorting out was complete, uncertainty in financial markets would decline, the stock market would undergo a recovery, and interest rates would fall. The result would then be a diminution in adverse selection and moral hazard problems, the spread between interest rates on low and high quality bonds would decline, and the financial crisis would subside. With the financial markets able to operate well again, the stage would be set for the recovery of the economy.

However, in other episodes, such as the 1873 panic and the Great Depression, the economic downturn and contraction of the money supply resulting from the bank panic led to a sharp decline in prices. With the unanticipated deflation, the recovery process might get shortcircuited. In this situation described by Irving Fisher (1933) as a debt-deflation, the unanticipated deflation led to a further deterioration in firms' net worth because of the increased burden of indebtedness. As we have seen, when debt-deflation set in, the adverse selection and moral hazard problems continued to increase. As a result, investment spending and aggregate economic activity remained depressed for a long time.

There are several conclusions that can be drawn from studying the U.S. episodes. The timing and the pattern of the data in the episodes seem to fit an asymmetric information interpretation of financial crises. Rather than starting with bank panics, most financial crises began with a rise in interest rates, a stock market crash and the widening of the interest rate spread. Furthermore, a financial panic frequently was immediately preceded by a major failure of a financial firm and the beginning of the recession which increased uncertainty in the 
marketplace. The increase in uncertainty and the rise in interest rates magnified the adverse selection problem in the credit markets, while the decline in the stock market increased adverse selection and moral hazard problems. The increase in adverse selection and moral hazard problems then led to a decline in investment activity and aggregate economic activity.

Only after these problems have manifested themselves in financial markets do we find that a bank panic occurs. Thus the theory helps to explain the timing of banking panics, that is, why they occurred when they did because it sees bank panics as a consequence of high interest rates, a major failure of a corporation or a nonbank financial institution, or weak business conditions stemming from a recession which make depositors nervous about the health of banks that hold their deposits. Since depositors cannot easily screen out good from bad banks, when this adverse aggregate information appears, they worry about potential losses on their deposits and withdraw funds from the banking system, precipitating a panic. The facts about the crisis episodes discussed in Mishkin (1991) are thus entirely consistent with Gorton's (1988) view that bank panics are predictable. ${ }^{19}$

Once a bank panic sets in, the resulting loss of liquidity causes interest rates to rise further, the stock market to decline even more and the adverse selection and moral hazard to worsen. Finally, the sorting out of solvent from insolvent firms and banks occurs, the crisis then subsides, the stock market undergoes a recovery, interest rates fall, and if economic uncertainty and unanticipated deflation were not too severe, adverse selection and moral hazard problems would diminish. In episodes in which a substantial deflation does not occur, we then expect and do see a rapid decline in the spread between interest rates for low versus high-quality borrowers. However, in episodes in which a substantial deflation sets in, we see evidence of a debt-deflation process in which aggregate economic activity is depressed for a prolonged period of time.

\footnotetext{
${ }^{19}$ This timing of bank crises is also what is typically found in developing countries and is consistent with asymmetric information theory. See Gavin and Hausman (1995) and Kaminsky and Reinhardt (1996).
} 


\section{Mexico, 1994-95.}

Because of the different institutional features of Mexico's debt markets, the sequence of events in the 1994-95 Mexican banking and financial crisis which began in December of 1994 is different from that which occurred in the United States in the nineteenth and twentieth centuries. Figure 2 provides a diagrammatic exposition of the sequence of events that occurred in the Mexican case.

An important factor leading up to the Mexican financial crisis was the deterioration in banks' balance sheets because of increasing loan losses. As we saw in the discussion of the U.S. savings and loan debacle, deregulation of a financial system and rapid credit growth can be disastrous if banking institutions and their regulators do not have sufficient expertise to keep risk taking in check. A similar situation occurred in Mexico. In September 1982, Mexican banks were nationalized and not surprisingly, these nationalized banks directed a large percentage of their lending business to the government -- on the order of 50 percent. When these banks were privatized in the early 1990s, their expertise in making loans to private firms and individuals was somewhat limited. For example, Mexican banks did not have formal credit bureaus for household and small business lending which would monitor loans to make sure that borrowers were not taking on excessive risk. In addition, as Figure 3 indicates, bank credit to the private nonfinancial business sector as a fraction of GDP accelerated dramatically, going from $10 \%$ of GDP in 1988 to over $40 \%$ of GDP in 1994 . This lending boom, which stressed the screening and monitoring facilities of the banks, occurred both as a result of increased savings which flowed into the banking sector and an increasing share of banks' total lending going to private firms.

Furthermore, the primary regulator of banks in Mexico, the National Banking Commission (Comision Nacional Bancaria), also did not have the capability to monitor banks' loan portfolios and management practices to prevent inordinate risk taking. This lack of capabilities was exacerbated not only by the bank lending boom, but also by the tremendous expansion in lending by other financial institutions, such as credit unions, thrifts, and factoring and leasing companies. Not surprisingly, given what we have seen in situations like this in the 
Figure 2

\section{The Sequence of Events in the Mexican Financial Crises of 1994-1995}

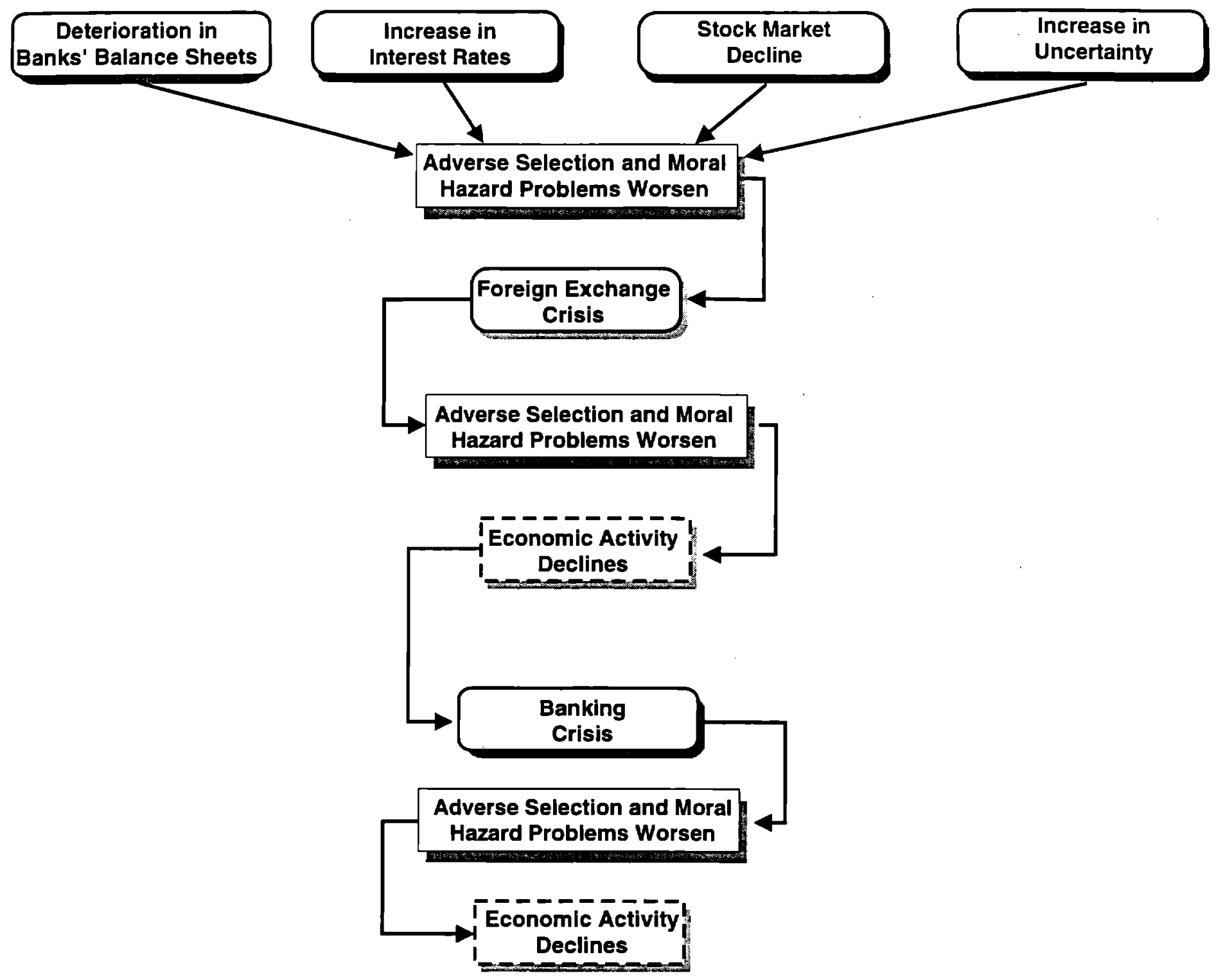

Factors Causing Financial Crises:

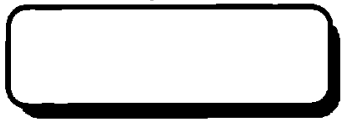

Consequences of Changes in Factors:

Adverse Selection and Moral

Hazard Problems Worsen

Heras

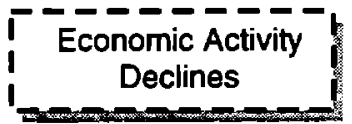




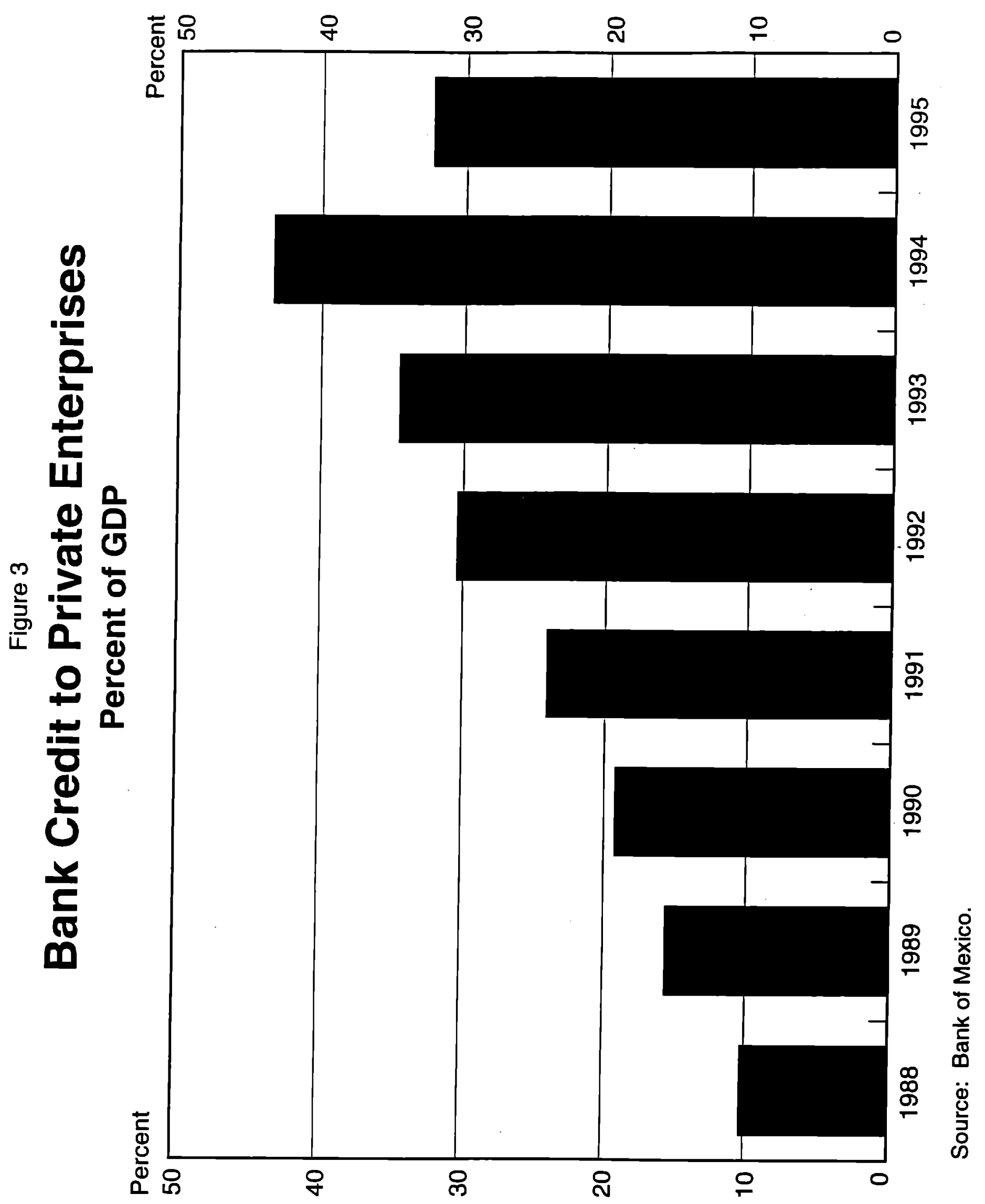


United States and also in the Nordic countries, when Mexican banks and nonbank financial institutions expanded their loan activities, they did indeed take on excessive risk and many bad loans were the result. Figure 4 shows the increase in bank loan losses in the 1990s as reported by National Banking Commission. However, these numbers understate the extent of the growing problem because they would be substantially higher using U.S. generally accepted accounting principles.

Consistent with the U.S. experience in the nineteenth and early twentieth centuries, another precipitating factor to the Mexican financial crisis was a rise in interest rates abroad. Beginning in February 1994, the Federal Reserve began to raise the interbank federal funds rate in order to proactively prevent incipient inflationary pressures from taking hold. Although this policy has been quite successful in keeping inflation in check in the U.S., as Figure 5 indicates, it did put upward pressure on Mexican interest rates, increasing asymmetric information problems in the Mexican financial system. ${ }^{20}$ Another factor leading to the rise in Mexican interest rates was central bank actions to protect the value of the peso in the foreign exchange market when the peso came under attack. The rise in interest rates directly added to increased adverse selection in Mexican financial markets because, as discussed earlier, it made it more likely that those willing to take on the most risk would seek loans.

Even more importantly, increased interest payments caused reductions in households' and firms' cash flow, which led to a deterioration in their balance sheets. Recall that debt contracts in Mexican financial markets have very short durations. Thus, the rise in Mexican short-term interest rates, which occurred partially as a result of rising short-term rates in the United States, meant that the effect on cash flow and hence on balance sheets would be substantial. We see this in Figure 6 which shows the net creditor or debtor position of both households and firms over the period 1987 through September 1995. The deterioration in households' balance sheets was quite sharp after the rise in Mexican interest rates in early 1994, while that for firms shows

\footnotetext{
${ }^{20}$ Bank of Mexico officials believe that the interbank interest rate (TIIP, tasa interbancaria promedio) is a better measure of money market interest rates than that on cetes, the peso denominated Treasury bills. Cetes rates might have been artificially low because cetes were required to be held in certain domestic investment funds and foreigners were discouraged from purchasing other money market instruments besides cetes by regulations in their own countries, making cetes the instrument generally used for repurchase operations.
} 


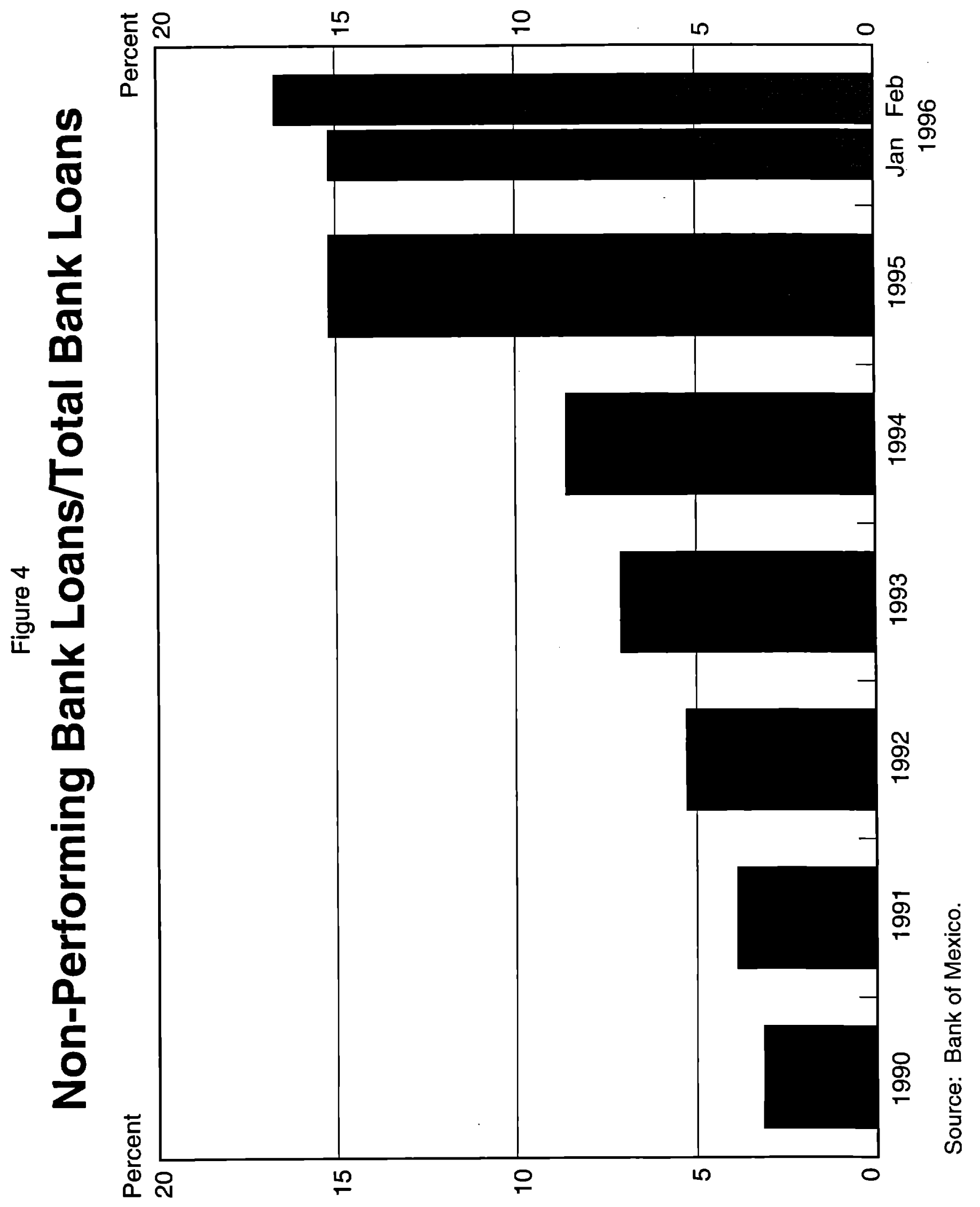




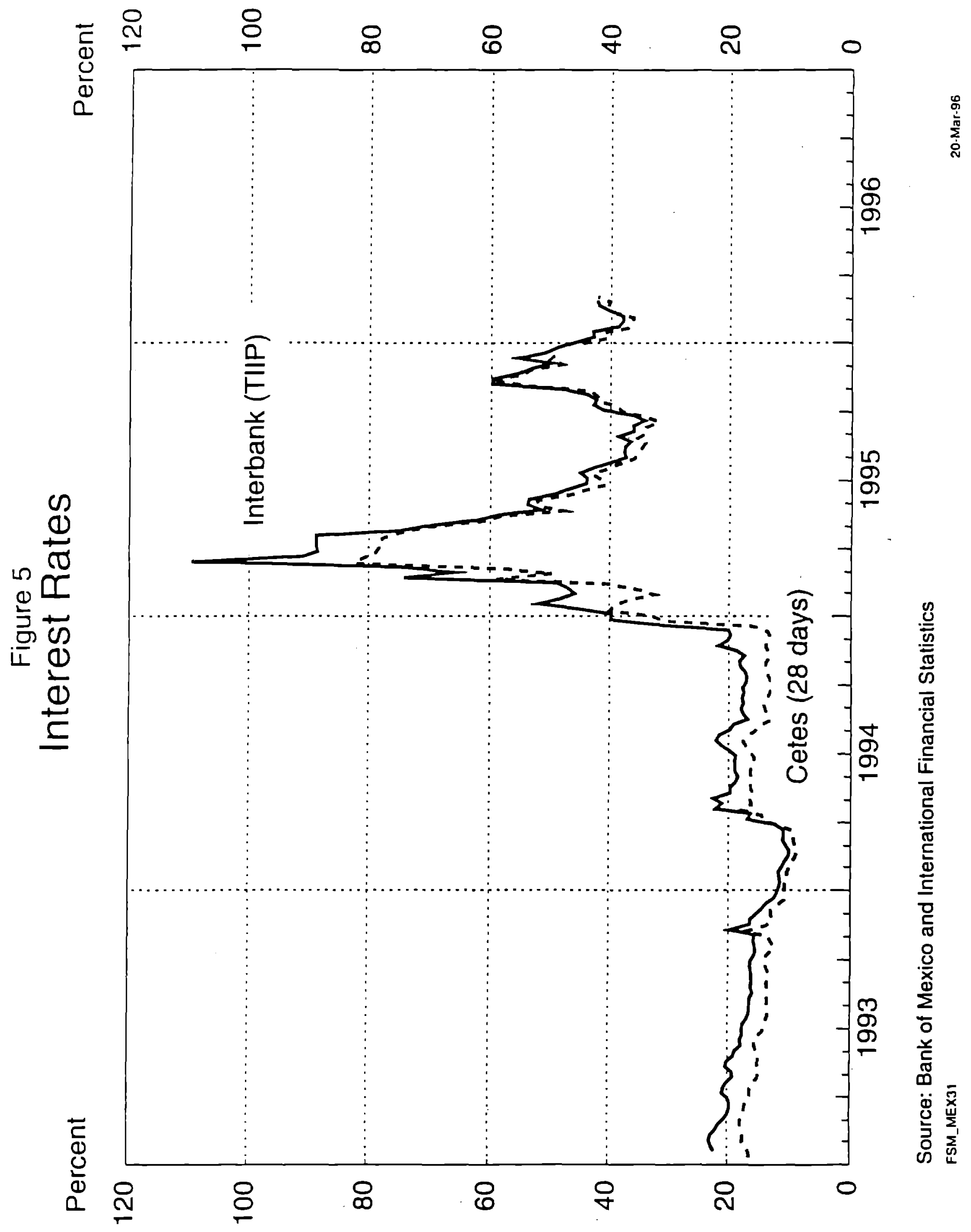




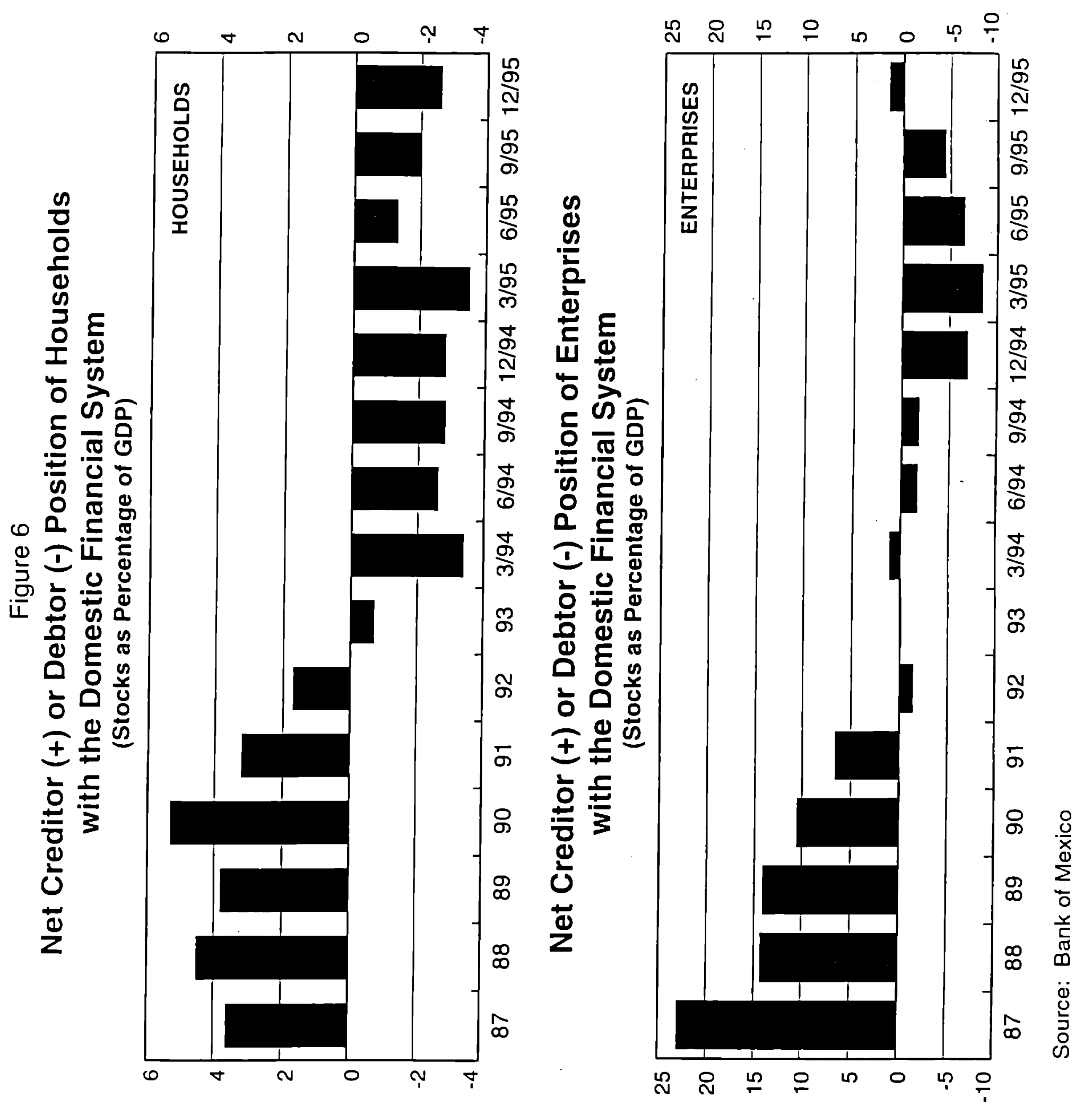


a less dramatic but steady deterioration. As asymmetric information theory suggests, this deterioration in households' and firms' balance sheets increased adverse selection and moral hazard problems in Mexican financial markets which made it less desirable for lenders to lend.

Also consistent with the U.S. experience in the nineteenth and early twentieth centuries, increases in uncertainty in Mexican financial markets and a stock market decline precipitated the full blown financial crisis. The Mexican economy was hit by political shocks in 1994, specifically the Colosio assassination and the uprising in Chiapas, which increased general uncertainty in Mexican financial markets. In addition, as shown in Figure 7, stock prices on the Bolsa fell nearly 20\% from the peak in September 1994 to the middle of December 1994. As we have seen, an increase in uncertainty and the decline in net worth as a result of the stock market decline increase asymmetric information problems because it is harder to screen out good from bad borrowers and the decline in net worth decreases the value of firms' collateral and increases their incentives to make risky investments since there is less equity to lose if the investments are unsuccessful. The increase in uncertainty and the stock market decline, along with increases in interest rates and the deterioration in banks' balance sheets, were initial conditions that worsened adverse selection and moral hazard problems (shown in the top of the diagram in Figure 2) and made the Mexican economy ripe for a serious financial crisis when a full blown crisis developed in the foreign exchange market.

With the Colosio assassination and other political developments such as the uprising in Chiapas, the Mexican peso began to come under attack. Given the commitment to a pegged exchange rate, the Banco de Mexico intervened in the foreign exchange market to purchase pesos, with the result that there was a substantial loss of international reserves (see Figure 8). In addition, because of the uncertainty in the foreign exchange market, the government found it harder to finance its debt with peso denominated (cetes) bonds and so dramatically increased its issue of dollar denominated (tesobono) bonds, depicted in Figure 9. Even though the Mexican central bank raised interest rates sharply, the hemorrhaging of international reserves forced the Mexican authorities to devalue the peso on December 20, 1994.

The institutional structure of debt markets in Mexico now interacted with the peso devaluation to propel the economy into a full fledged financial crisis. Devaluations are a highly nonlinear event, because they result in a sharp change in the exchange rate. When the peso 


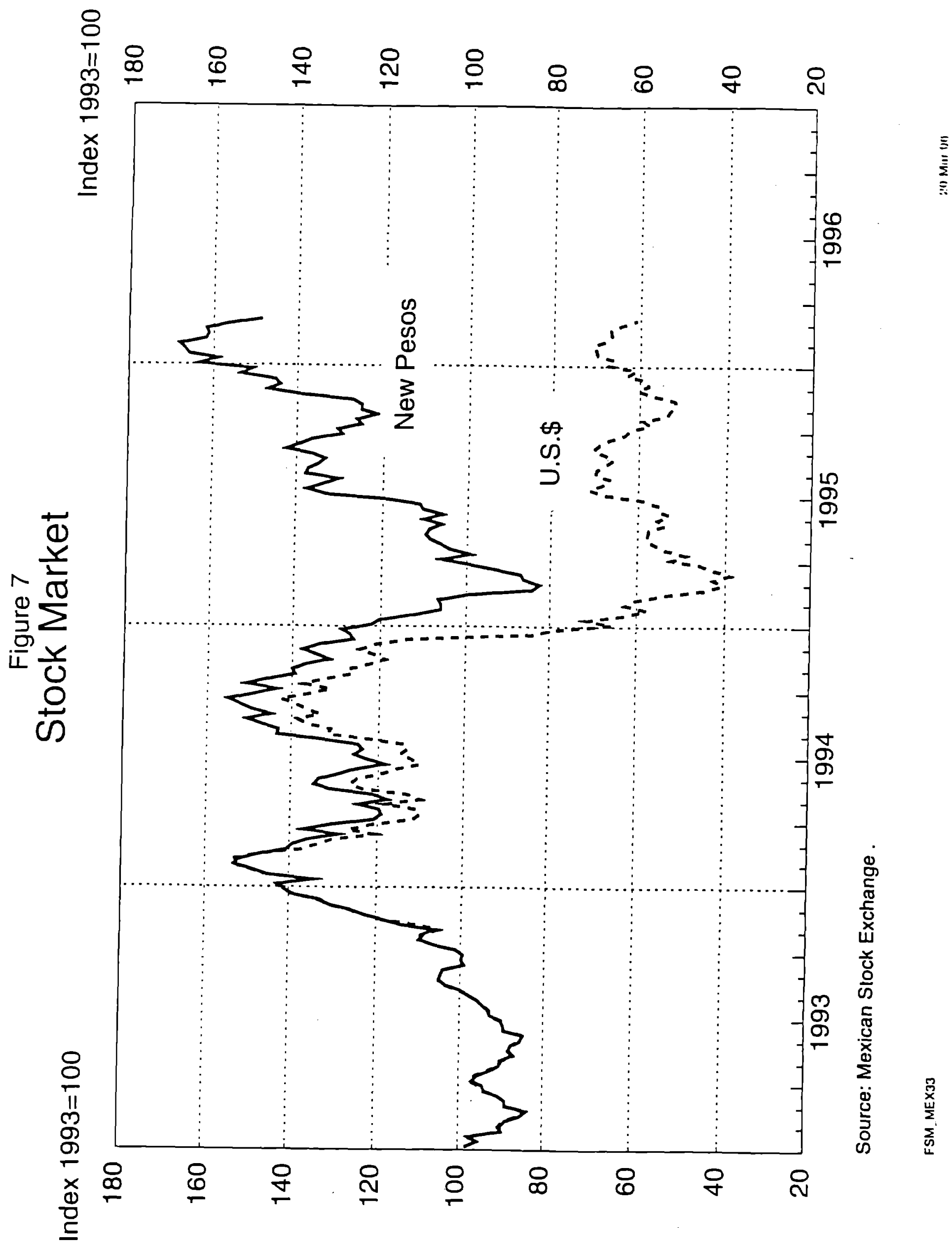




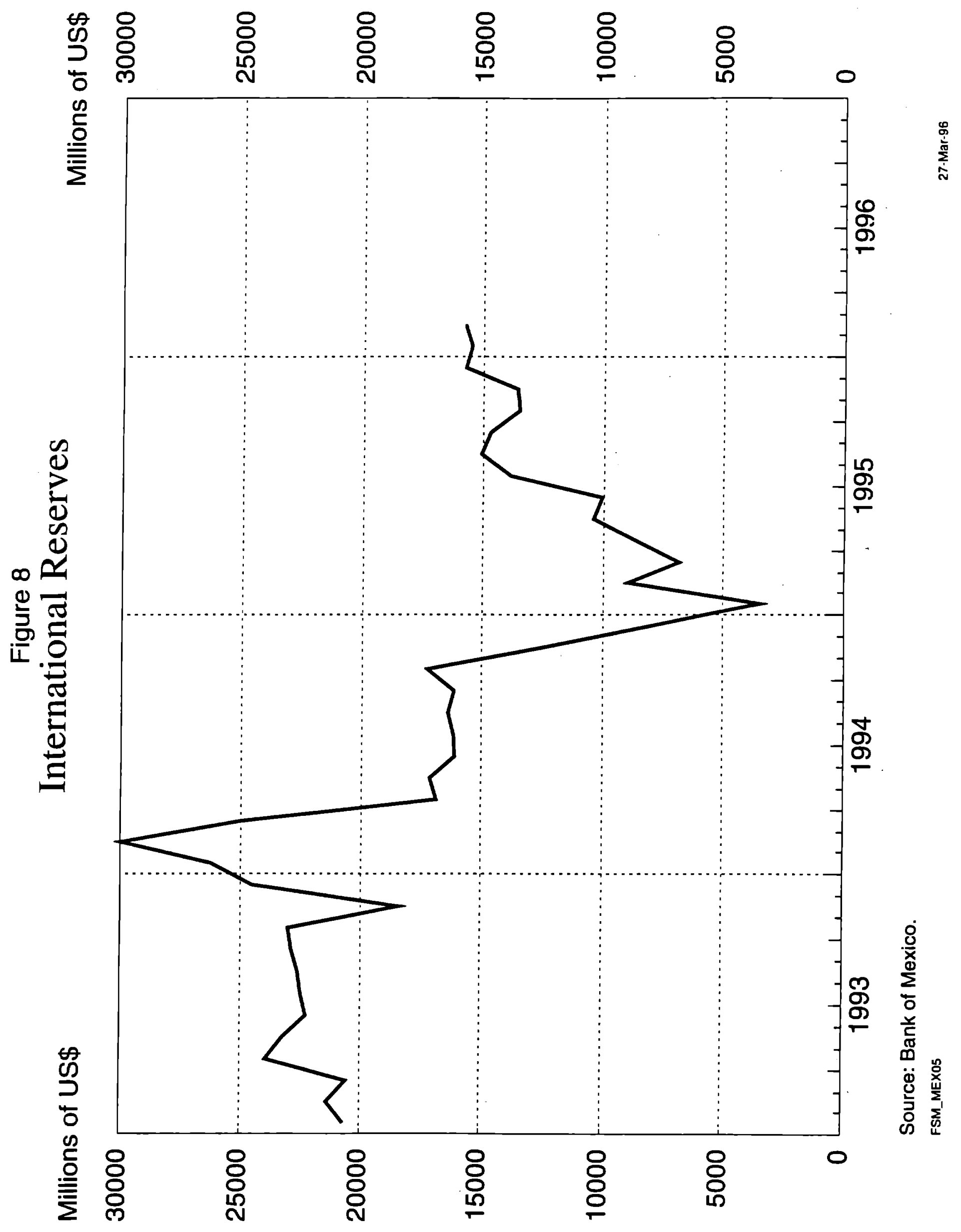




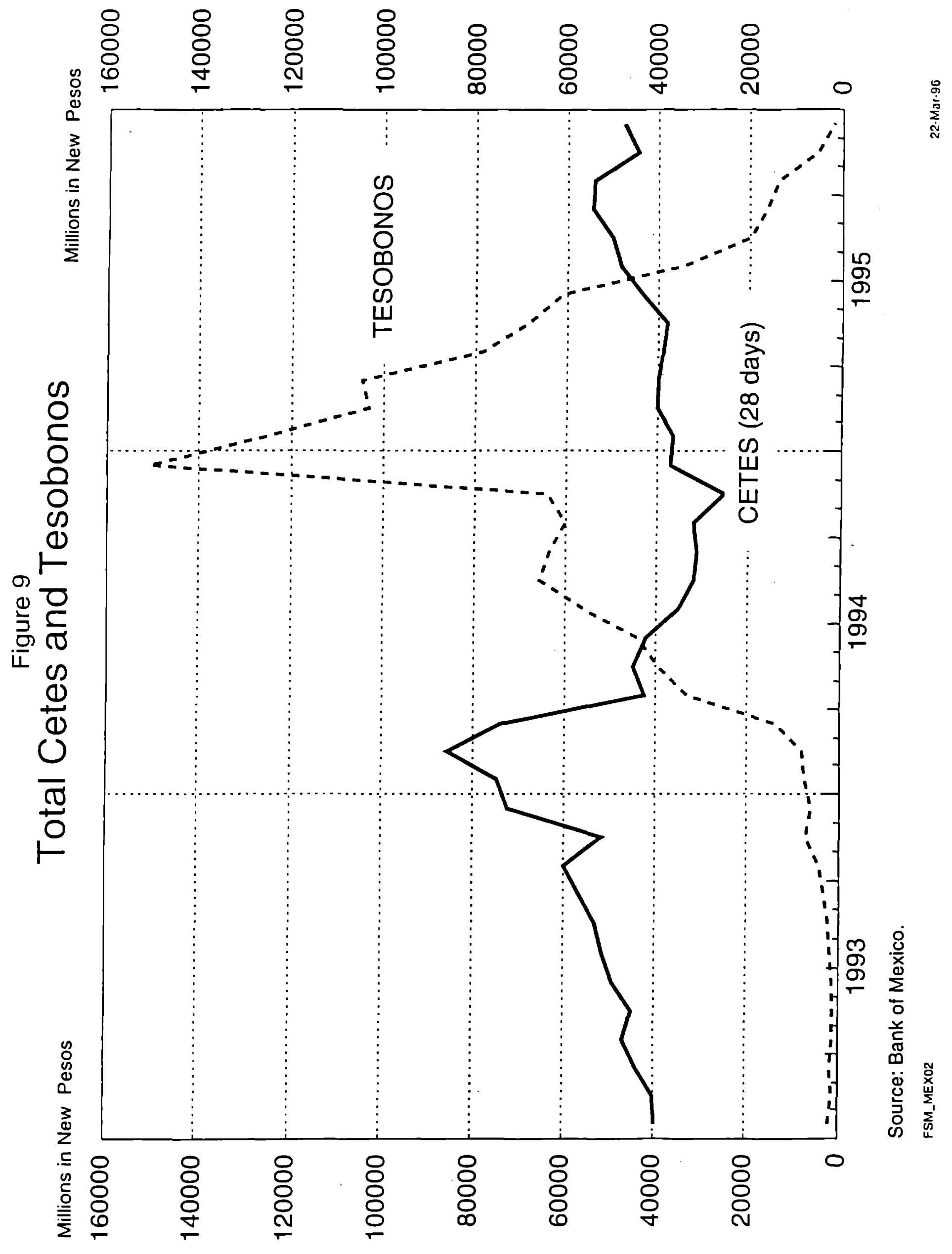


halved in value by March 1995 (see Figure 10), this led to a dramatic rise in both actual (Figure 11) and expected inflation. This combined with the desire of the Banco de Mexico and the Mexican government to limit the peso depreciation meant that interest rates on debt denominated in pesos went to sky high levels, exceeding $100 \%$ at an annual rate and the Mexican stock market crashed, falling another $30 \%$ in peso terms and by over $60 \%$ in dollar terms. Given the resulting huge increase in interest payments because of the short duration of the Mexican debt, households' and firms' cash flow dropped dramatically, leading to a deterioration in their balance sheets. In addition, because many firms had debts denominated in dollars, the depreciation of the peso resulted in an immediate sharp increase in their indebtedness in pesos, while the value of their assets remained unchanged. As we see in Figure 6, the depreciation of the dollar starting in December 1994 led to an especially sharp negative shock to the net worth of private firms, causing a dramatic increase in adverse selection and moral hazard problems. These asymmetric information problems were severe for domestic lenders, and for foreign lenders as well because they also had difficulty obtaining information about what was going on in the Mexican economy. Foreign lenders would thus be even more eager to pull their funds out of Mexico and this is exactly what they did. As Figure 12 shows, foreign portfolio investment inflows to Mexico which were on the order \$20 billion (at an annual rate) in 1993 and early 1994, reversed course and the outflows exceeded $\$ 10$ billion at an annual rate beginning in the fourth quarter of 1994 . Consistent with the theory of financial crises outlined in this paper, the sharp decline in lending helped lead to a collapse of economic activity, with real GDP growth falling from around a $4 \%$ to $4.5 \%$ annual rate in the last half of 1994 to negative growth rates in the $-10 \%$ vicinity in the second and third quarters of 1995 . (See Figure 13.)

As shown in the diagram in Figure 2, further deterioration to the economy now occurred because the collapse in economic activity and the deterioration in the cash flow and balance sheets of both firms and households led to a worsening banking crisis. The problems of firms and households meant that many were no longer able to pay off their debts, resulting in substantial loan losses for the banks. In addition, the depreciation of the peso had a direct negative impact on banks' balance sheets. As Table 1 shows, the foreign-currency denominated liabilities of Mexican banks jumped from 88.8 billion pesos at the end of December 1993 to 


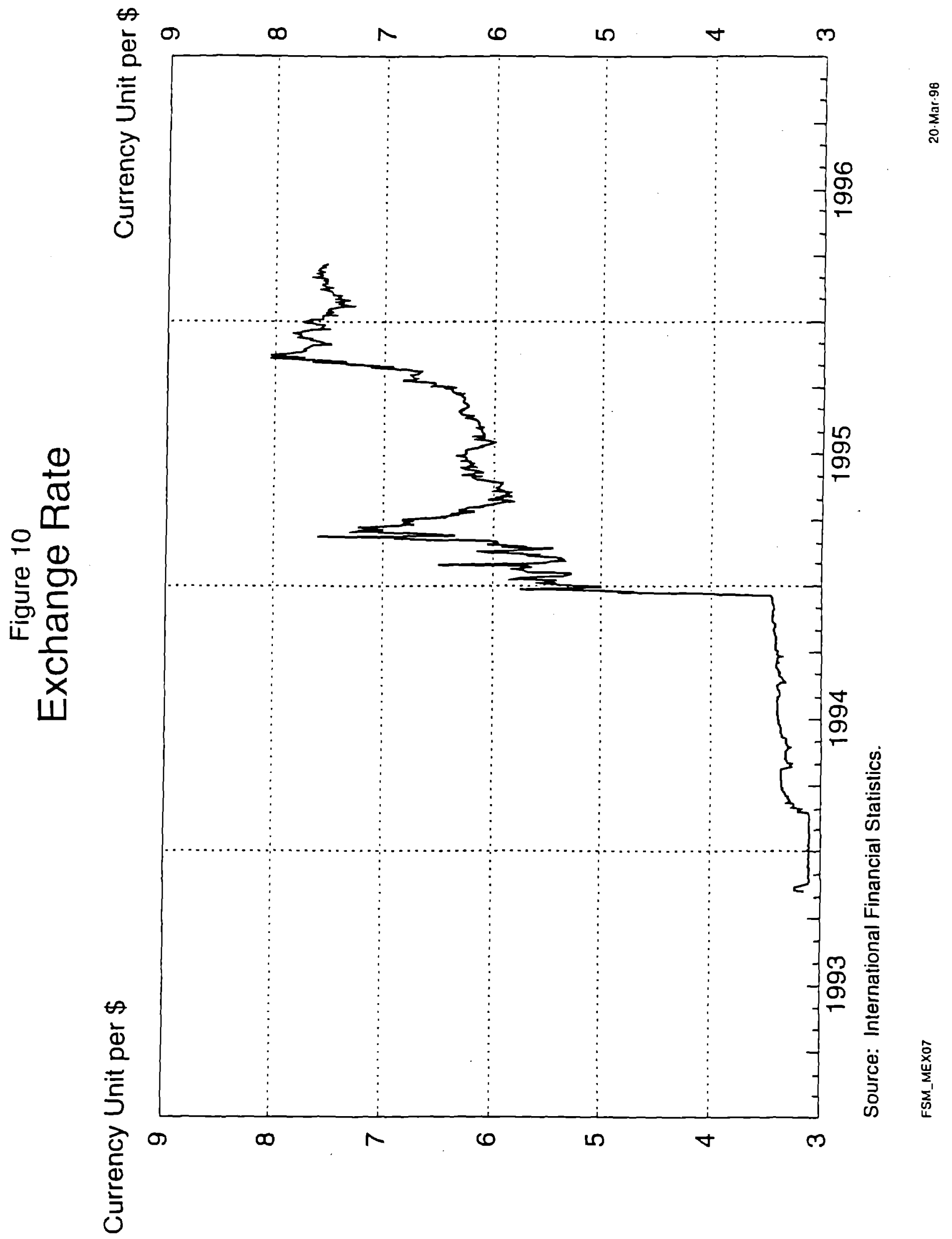




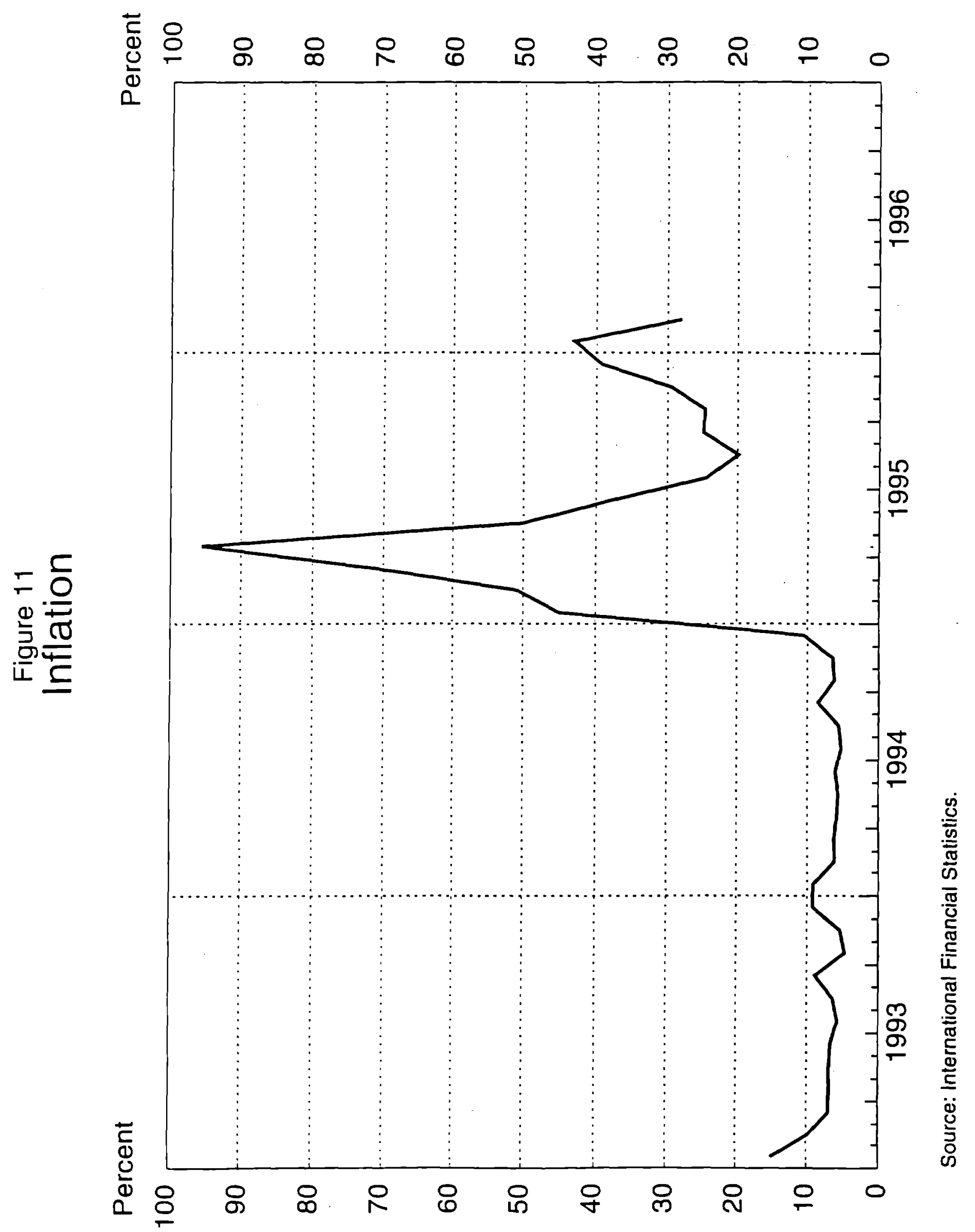




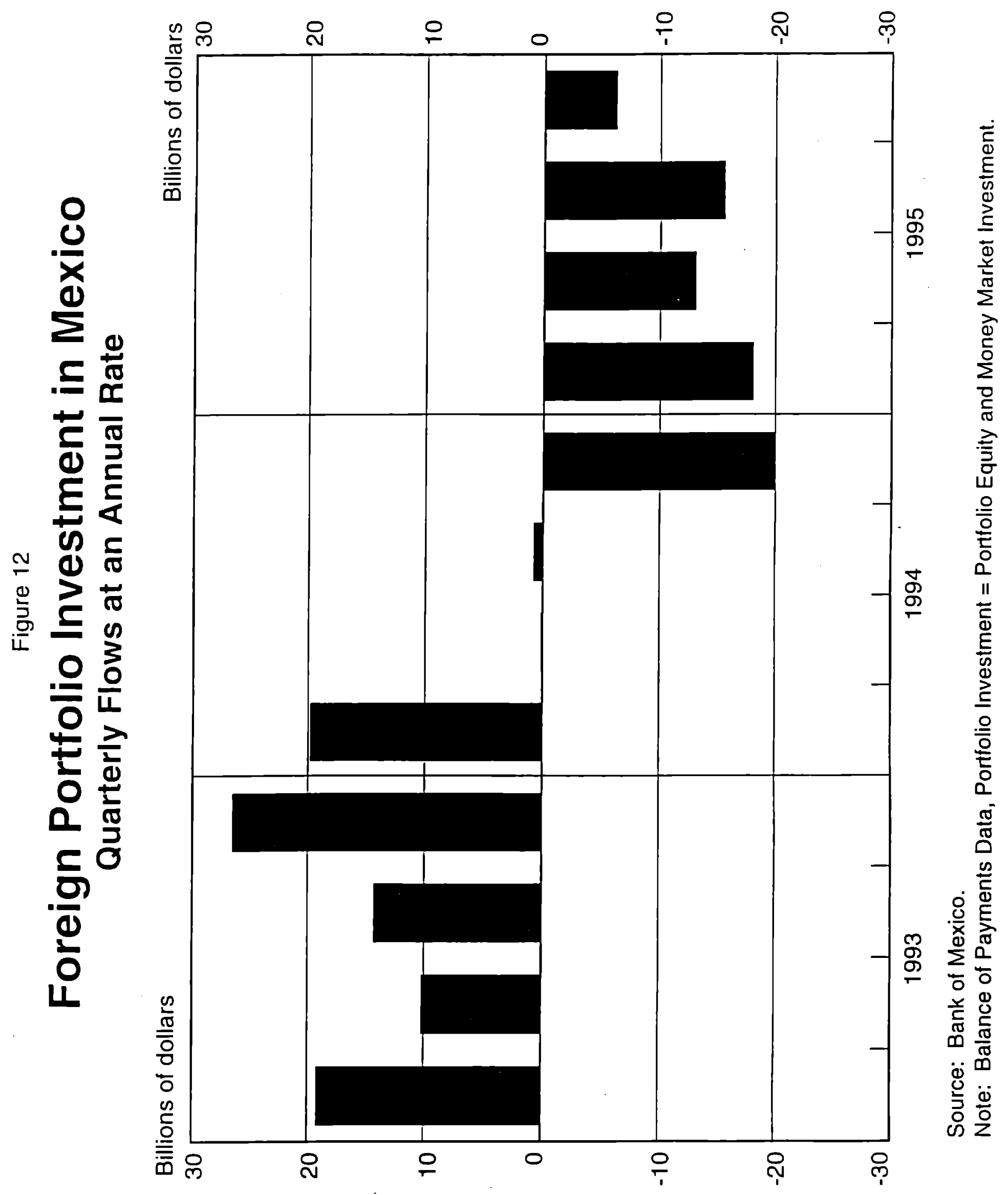




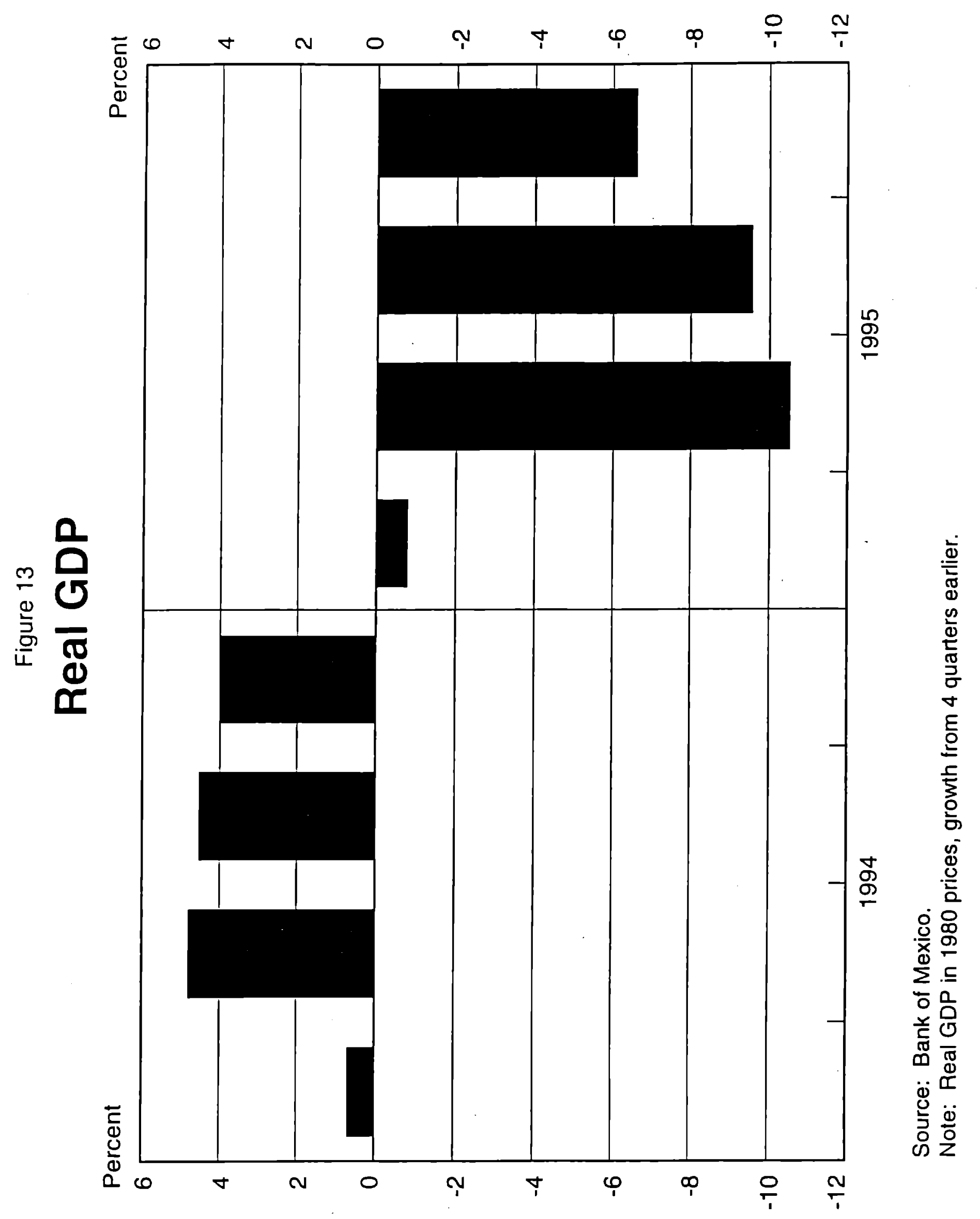




$$
\begin{aligned}
& \text { 1 }
\end{aligned}
$$

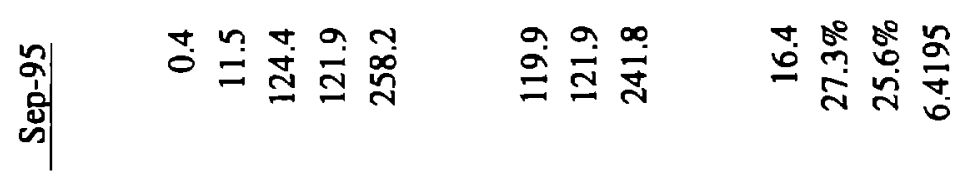

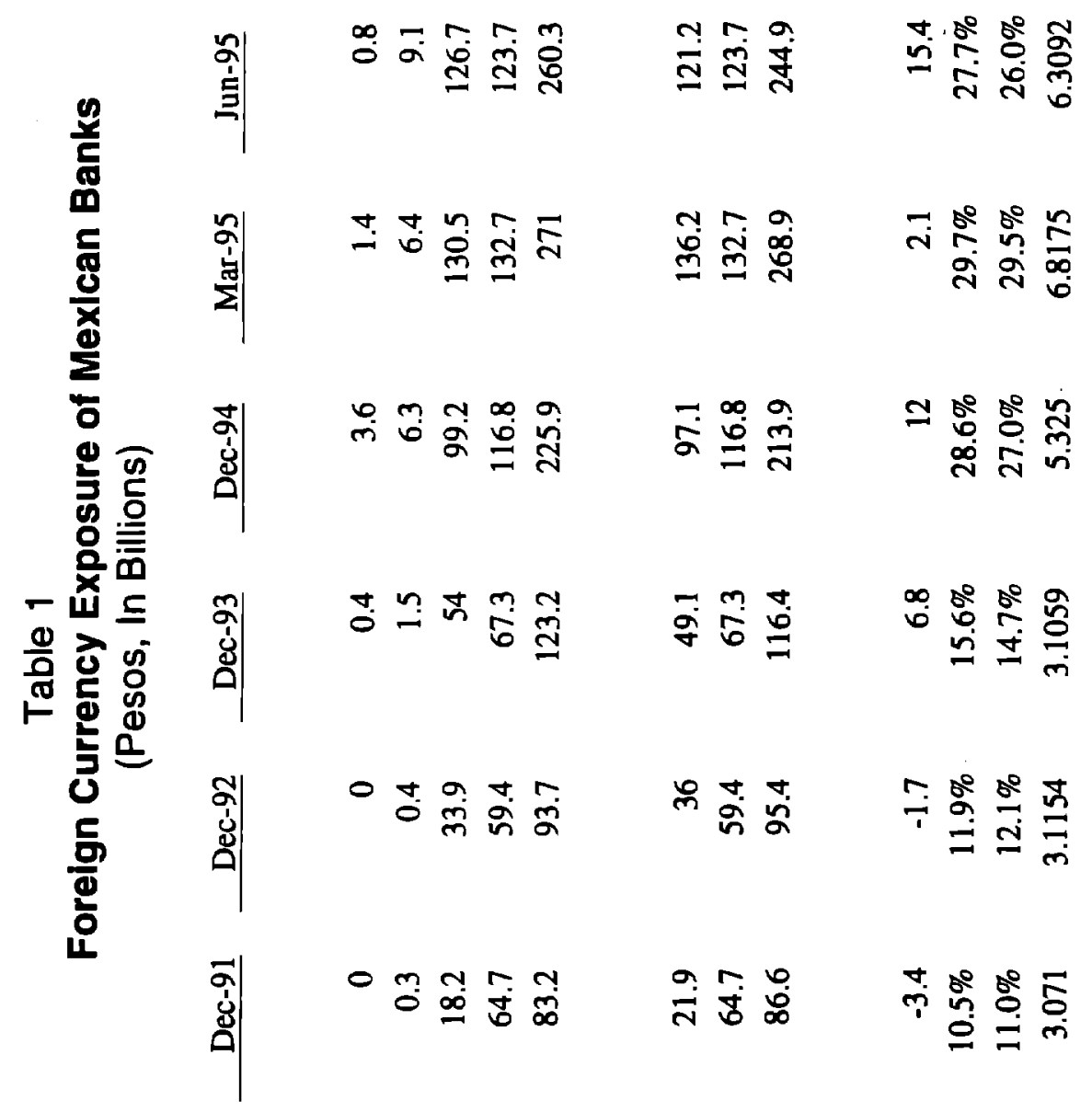

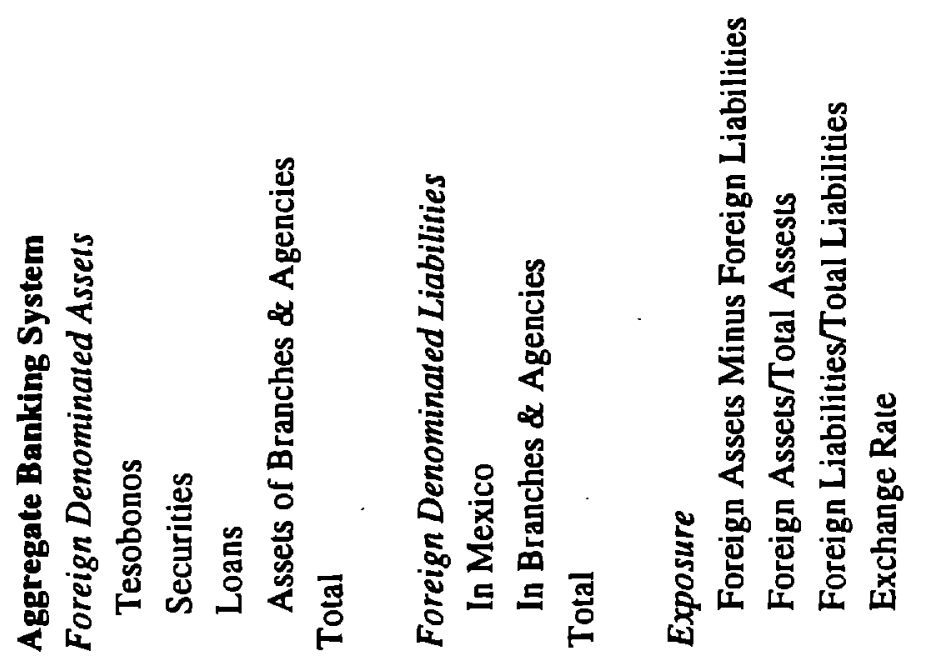


174.4 billion pesos at the end of December 1994, primarily as a result of the decline in the peso from 3.1 to the dollar to 5.3 to the dollar. Although, as Table 1 shows, Mexican banks did have offsetting foreign-currency denominated assets, their likelihood of being paid off in full was substantially lowered because of the worsening business conditions and the negative effect that these increases in the peso value of these foreign-currency denominated loans had on the balance sheet of the borrowing firms. An important point is that even if banks have a matched portfolio of foreign-currency denominated assets and liabilities and so appear to avoid foreign-exchange market risk, a devaluation can nonetheless cause substantial harm to bank balance sheets; when there is a devaluation, the mismatch between foreign-currency denominated assets and liabilities on borrowers balance sheets can lead to defaults on their loans, thereby converting a market risk for borrowers to a credit risk for the banks that have made the foreign-currency denominated loans.

Even more problematic for the Mexican banks is that many of their foreign-currency denominated liabilities were very short-term, so that the sharp increase in the value of these liabilities led to liquidity problems for the banks because they had to be paid back quickly. Given the problems of the banking system, the collapse of the banking system would then have been the inevitable result in the absence of a government safety net, but instead the Mexican government provided the funds to protect depositors, thereby avoiding a bank panic. ${ }^{21}$ However, given the banks' loss of capital and the need for the government to intervene to prop up the banks, the banks' ability and willingness to lend were sharply curtailed. As we have seen, a banking crisis of this type which hinders the ability of banks to lend also makes adverse selection and moral hazard problems worse in financial markets because banks are no longer as capable of playing their traditional financial intermediation role.

The theory of banking and financial crises outlined in this paper provides a cohesive story behind the sequence of events that developed in the Mexican crisis of 1994-95. In addition, it explains the puzzle mentioned in the introduction to this paper: it shows how a developing economy can shift dramatically from a path of reasonable growth before a financial crisis, as

\footnotetext{
${ }^{21}$ The National Banking Commission has estimated that the present value of the initial cost of this assistance was $5.1 \%$ of GDP, while additional measures raise the cost to $5.5 \%$ of GDP.
} 
was the case in Mexico in 1994, to a sharp decline in economic activity after a crisis occurs. The answer is that the financial crisis leads to such a substantial worsening of adverse selection and moral hazard problems in financial markets that there is a collapse of lending and hence in economic activity. ${ }^{22}$

\section{VI. \\ Policy Measures to Recover from Financial Crises}

Given the disastrous consequences of financial crises, it is extremely important to examine what steps policy makers can take to recover from financial crises and minimize the effects on the economy. Given our earlier discussion, it is not surprising that the institutional structure of the financial system plays an important role in what measures can be used by the authorities to stimulate recovery from a financial crisis. Indeed, to focus on the special problems that developing countries face in recovering from financial crises, we first focus on policy measures that can be taken in developed countries and show how the differing institutional framework for developing countries means that these measures may not work or may even be counterproductive in developing countries.

\section{Developed Countries}

The institutional structure of financial systems in most developed countries has two features that are very important in enabling central banks in these countries to stimulate recovery from financial crises: 1) Debt contracts are almost solely denominated in domestic currency;

\footnotetext{
${ }^{22}$ Of course, other factors contributed to the economic downturn such as the traditional effects from the contractionary fiscal policy and tight monetary policy.
} 
2) Because inflation has tended to be moderate, many debt contracts are of fairly long duration.

One method for a central bank to promote recovery from a financial crisis given the above institutional structure is to pursue an expansionary monetary policy by injecting liquidity (reserves) into the financial system. Injecting reserves, either through open market operations or by lending to the banking sector, causes the money supply to increase, which in turns leads to a higher price level. Given that debt contracts are denominated in domestic currency and many debt contracts are of fairly long duration, the higher price level produces the opposite of the unanticipated disinflation mechanism described earlier. The reflation of the economy causes the debt burden of households and firms to fall, thereby increasing their net worth. As outlined earlier, higher net worth then leads to reduced adverse selection and moral hazard problems in financial markets, undoing the increase in adverse selection and moral hazard problems induced by the financial crisis. In addition, injecting liquidity into the economy raises asset prices such as land and stock market values, which also cause an improvement in net worth and a reduction in adverse selection and moral hazard problems. Also, as discussed in Mishkin (1996), expansionary monetary policy promotes economic recovery through other mechanisms involving the stock market and the foreign exchange market. ${ }^{23}$

The Federal Reserve's expansionary monetary policy and reflation of the economy was an important element in the recovery from the Great Depression in the United States after 1933. ${ }^{24}$ By increasing reserves and the money supply, the Federal Reserve helped stimulate the price level and induce other asset prices to rise. As a result, the financial markets recovered and the economy then grew rapidly. The recent experience in Japan again demonstrates the

\footnotetext{
${ }^{23}$ Note that not all developed countries are alike in their ability to use expansionary monetary policy to recover from a financial crisis. If a country has a commitment to peg its exchange rate to a foreign currency, then expansionary monetary policy may not be an available tool to promote recovery because pursuing such a policy might force a devaluation of its currency. This problem is of course particularly acute for a small country in a pegged exchange rate regime. Even if a country has a flexible exchange rate, expansionary monetary policy to promote recovery might cause a depreciation of the domestic currency which is considered to be intolerable by the authorities, particularly in smaller countries. Clearly, a large reserve currency country like the United States has the most flexibility to use expansionary monetary policy to reflate the economy as a tool to recover from or reduce the probability of a financial crisis.
}

${ }^{24}$ For example, see Romer (1992). 
effectiveness of expansionary monetary policy to stimulate the economy in the face of a banking crisis. In 1995, the Bank of Japan began to pursue a more expansionary monetary policy in which nominal interest rates have been kept very low and the growth rate of the monetary base increased. The result has been a sharp increase in stock market prices, a slowdown in the deflationary process, and some encouraging signs of an economic recovery in 1996.

A second method for a central bank to promote recovery from a financial crisis is to pursue the so-called lender-of-last-resort role in which the central bank stands ready to lend freely during a financial crisis. A textbook example ${ }^{25}$ of this role occurred in the United States in the aftermath of the stock market crash of October 19, 1987. Although October 19, 1987, dubbed "Black Monday," will go down in history as the largest one-day decline in stock prices to date, it was on Tuesday, October 20,1987, that financial markets received their worst threat. In order to keep the stock market and the related index futures market functioning in an orderly fashion, brokers needed to extend massive amounts of credit on behalf of their customers for their margin calls. The magnitude of the problem is illustrated by the fact that just two brokerage firms, Kidder, Peabody and Goldman, Sachs, had advanced $\$ 1.5$ billion in response to margin calls on their customers by noon of October 20. Clearly, brokerage firms as well as specialists were severely in need of additional funds to finance their activities. However, understandably enough, banks were growing very nervous about the financial health of securities firms and so were reluctant to lend to the securities industry at a time when it was most needed.

According to Brimmer (1989), upon learning of the plight of the securities industry, Alan Greenspan and E. Gerald Corrigan, the president of the New York Federal Reserve Bank and the Fed official most closely in touch with Wall Street, began to fear a breakdown in the clearing and settlement systems and the collapse of securities firms. To prevent this from occurring, Alan Greenspan announced before the market opened on Tuesday, October 20, the Federal Reserve System's "readiness to serve as a source of liquidity to support the economic and financial system." In addition to this extraordinary announcement, the Fed encouraged key money center banks to lend to their brokerage firm customers, and made it clear that sufficient liquidity would be available to banks so that they could make these loans if it were necessary.

\footnotetext{
${ }^{25}$ Indeed this example is discussed prominently in my textbook, Mishkin (1995).
} 
(As it turned out, the Federal Reserve made liquidity available through open market operations rather than with discount loans.) The banks did as they were encouraged and by October 21 had increased by $\$ 7.7$ billion their loans to brokers and to individuals to purchase or hold securities. As a result, the markets kept functioning on Tuesday, October 20 and a market rally ensued that day, raising the Dow Jones Industrial Average by over 100 points (over $5 \%$ ).

Evidence in Mishkin (1991) demonstrates that the stock market crash in October 1987 did have the potential to produce a financial crisis, but the prompt action of the Federal Reserve prevented the crisis from spinning out of control. Indeed, one lesson from this episode is that very quick action on the part of the central bank often means that the actual amount of lending needed can be very small. The quicker the intervention, the smaller the amount of lending that is required.

\section{Developing Countries}

Institutional features of the financial systems in developing countries imply that it may be far more difficult for the central bank to promote recovery from a financial crisis. As mentioned before, many developing countries have much of their debt denominated in foreign currency. Furthermore, their past record of high and variable inflation has resulted in debt contracts of very short duration and expansionary monetary is likely to cause expected inflation to rise dramatically.

As a result of these institutional features, a central bank in a developing country can no longer use expansionary monetary policy to promote recovery from a financial crisis. Suppose that the policy prescription for a developed country to pursue expansionary monetary policy and reflate the economy were followed in a developing country with the above institutional structure. In this case the expansionary monetary policy is likely to cause expected inflation to rise dramatically and the domestic currency to depreciate sharply. As we have seen before, the depreciation of the domestic currency leads to a deterioration in firms' and banks' balance sheets because much of their debt is denominated in foreign currency, thus raising the burden of 
indebtedness and lowering banks' and firms' net worth. In addition, the upward jump on expected inflation is likely to cause interest rates to rise because lenders need to be protected from the loss of purchasing power when they lend. As we have also seen, the resulting rise in interest rates causes interest payments to soar and the cash flow of households and firms to decline. Again the result is a deterioration in households' and firms' balance sheets, and potentially greater loan losses to banking institutions. Also because debt contracts are of very short duration, the rise in the price level from expansionary monetary policy does not affect the value of households' and firms' debts appreciably, so there is little benefit to their balance sheets from this mechanism as occurs in developed countries.

The net result of an expansionary monetary policy in the developing country with the above institutional structure is that it hurts the balance sheets of households, firms, and banks. Thus, expansionary monetary policy has the opposite result to that found in developed countries after a financial crisis: it causes a deterioration in balance sheets and therefore amplifies adverse selection and moral hazard problems in financial markets caused by a financial crisis, rather than ameliorates them as in the developed country case.

For similar reasons, lender-of-last-resort activities by a central bank in a developing country, may not be as successful as in a developed country. When the Federal Reserve pursued a lender-of-last-resort role during the 1987 stock market crash, there was almost no sentiment in the markets that this would lead to substantially higher inflation. However, this is much less likely to be the case for a developing country. Given the past record on inflation, central bank lending to the financial system in the wake of a financial crisis which expands domestic credit might arouse fears of inflation spiraling out of control. We have already seen that if inflation expectations rise, leading to higher interest rates and exchange rate depreciation, cash flow and balance sheets will deteriorate making recovery from the financial crisis less likely. The lenderof-last-resort role of a central bank must be used far more cautiously in a developing country with the institutional structure outlined here because central bank lending is now a two-edged sword.

The above arguments suggest that recovery from a financial crisis in many developing countries is a much more complicated exercise than it is for developed countries. Expansionary monetary policy is not an option for stimulating recovery from a financial crisis in most 
developing countries, in contrast to developed countries. Monetary policy must be restricted to promoting low inflation and restoring confidence in the domestic currency and therefore cannot be used to meet an additional objective of stimulating recovery from a financial crisis. Indeed, a speedy recovery from a financial crisis in a developing country may require foreign assistance because liquidity provided from foreign sources does not lead to any of the undesirable consequences that result from the provision of liquidity by domestic authorities. There clearly are other policy measures to stimulate recovery from a financial crisis if expansionary monetary policy is not an option, but discussion of them is well beyond the scope of this paper. Instead, the analysis in this paper makes the important point that certain institutional structures make a developing country's economy more prone to financial crises and make it more difficult to extricate the country from a financial crisis if it occurs.

\section{VII. Policy Implications For Developing Countries}

Experience with past financial crises in developing countries has led many analysts to suggest policy measures for developing countries that can both reduce the likelihood of banking and financial crises, but also reduce the negative impact on the economy if they occur. One advantage of the asymmetric information analysis of banking and financial crises in this paper is that it provides a coherent rationale for many of these suggested policy measures. Thus, although the lessons for policy from the asymmetric information analysis in this paper are not entirely new, the analysis here can help us decide which policy measures are effective in preserving the health of a developing country's economy.

As we have seen, banks play a particularly important role in developing countries' financial systems, and thus crises in the banking sector are a particularly important element in developing countries' financial crises. Our asymmetric information framework suggests that there is an important need for a government safety net for the banking system -- the key feature 
of which is not deposit insurance -- in order to prevent bank panics. Although a safety net is important, it nonetheless increases the moral hazard incentives for excessive risk taking on the part of the banks. In developing countries this moral hazard problem for banks may be even more acute because it is more difficult to acquire information in developing countries than in developing countries. Developing countries therefore need to pay particular attention to creating and sustaining a strong bank regulatory/supervisory system to reduce excessive risk taking in their financial systems.

Encouraging a strong bank regulatory/supervisory system takes on several forms. First, bank regulatory/supervisory agencies in developing countries need to be provided with adequate resources to do their job effectively. Without these resources, as we have seen in the examples of the S\&L supervisors in the United States and the National Banking Commission in Mexico, the bank supervisory agency will not be able to monitor banks sufficiently in order to keep them from engaging in inappropriately risky activities, to have the appropriate management expertise and controls to manage risk, or to have sufficient capital so that moral hazard incentives to take on excessive risk are kept in check. Second, accounting and disclosure requirements for financial institutions, which are often particularly lacking in developing countries, need to be beefed up considerably. Without the appropriate information, both markets and bank supervisors will not be able to adequately monitor the banks to deter excessive risk taking. ${ }^{26}$ Proper accounting standards and disclosure requirements are therefore crucial to a healthy banking system.

Third, prompt corrective action by bank supervisors will stop undesirable bank activities and, even more importantly, close down institutions which do not have sufficient net worth and make sure that stockholders and managers of insolvent institutions are appropriately punished. Our asymmetric information framework indicates that prompt corrective action is particularly important, not only because it immediately prevents banks from "betting the bank" in order to restore the value of the institution, but also because it creates incentives for banks to not take on too much risk in the first place because they know that if they do, they are more likely to be

\footnotetext{
${ }^{26}$ The importance of disclosure is illustrated in a recent paper, Garber and Lall (1996), which suggests that off balance-sheet and off-shore derivatives contracts played an important role in the Mexican crisis.
} 
punished. Fourth, because prompt corrective action is so important, the bank regulatory/supervisory agency needs sufficient independence from the political process so that it is not encouraged to sweep problems under the rug and engage in regulatory forbearance. One way of doing this is to give the bank supervisory role to a politically independent central bank. This has desirable elements as pointed out in Mishkin (1991), but some central banks might not want to have the supervisory task thrust upon them because they worry that it might increase the likelihood that the central bank would be politicized, thereby impinging on the independence of the central bank. Alternatively, bank supervisory activities could be housed in a bank regulatory authority that is independent of the government.

Another measure to improve incentives for bank supervisors to do their job properly is to make them accountable if they engage in regulatory forbearance. For example, an important, but very often overlooked part of the 1991 FDICIA legislation in the United States which has helped make this legislation effective is that there is a mandatory report that the supervisory agencies must produce if the bank failure imposes costs on the Federal Deposit Insurance Corporation (FDIC). The resulting report is made available to any member of Congress and to the general public, upon request, and the General Accounting Office must do an annual review of these reports. Opening up the actions of bank supervisors to public scrutiny makes regulatory forbearance less attractive to them, thereby reducing the principal-agent problem. In addition, it reduces the incentives of politicians to lean on supervisors to relax their supervision of banks.

Deregulation and liberalization of the financial system in developing countries have become the rage in recent years. Although deregulation and liberalization are highly desirable objectives, the asymmetric information framework in this paper indicates that if this process is not managed properly, it can be disastrous. If the proper bank regulatory/supervisory structure is not in place when liberalization comes, the appropriate constraints on risk taking behavior will be nonexistent, with the result that bad loans are likely with potentially disastrous consequences for bank balance sheets at some point in the future. In addition, before liberalization occurs, banks may not have the expertise to make loans wisely, and so opening them up to new lending opportunities may also lead to poor quality of the loan portfolio. We have also seen that financial deregulation and liberalization also often lead to a lending boom, both because of increased opportunities for bank lending and also because of financial deepening in which more 
funds flow into the banking system. Although financial deepening is a positive development for the economy in the long run, in the short run the lending boom may outstrip the available information resources in the financial system, helping to promote a financial collapse in the future.

The dangers in financial deregulation and liberalization do not mean that developing countries should not pursue a liberalization strategy. To the contrary, financial liberalization is critical to the efficient functioning of financial markets so that they can channel funds to those with the most productive investment opportunities. Getting funds to those with the most productive investment opportunities is particularly critical to developing countries because these investments can have especially high returns in these countries, thereby stimulating rapid economic growth. Financial deregulation and liberalization thus needs to be actively pursued in developing countries, but has to be managed carefully. It is important that developing countries put in the proper bank regulatory/supervisory institutional structure before liberalizing their financial system. This means following the precepts outlined above of providing sufficient resources to bank supervisors, providing adequate accounting and disclosure requirements, encouraging bank supervisors to take prompt corrective action, and insulating bank supervision from the political process. Furthermore, developing countries may need to take the financial liberalization process slowly in order to keep a lending boom from getting out of hand which stresses the capabilities of both bank management and bank supervisors. Even though eating is essential to human health, eating too fast can lead to an upset stomach. A similar lesson applies to the process of financial deregulation and liberalization.

The asymmetric information framework for analyzing banking and financial crises also illustrates that institutional features of the financial system besides bank regulation can be critical to how prone a developing economy is to a financial crisis and to the severity of the effects on the economy if a financial crisis comes. The legal and judicial systems are very important for promoting the efficient functioning of the financial system and the inadequacies of legal systems in many developing countries are a serious problem for financial markets. If property rights are unclear or hard to enforce, the process of financial intermediation can be severely hampered. For example, we have seen that collateral can be an effective mechanism to reduce adverse selection and moral hazard problems in credit markets because it reduces the lender's losses in 
the case of a default. However, in many developing countries, the legal system makes attaching collateral a costly and time-consuming process, thereby reducing the effectiveness of collateral to solve asymmetric information problems. Similarly, bankruptcy procedures in developing countries are frequently very cumbersome, resulting in lengthy delays in resolving conflicting claims. Resolution of bankruptcies in which the books of insolvent firms are opened up and assets are redistributed can be viewed as a process to decrease asymmetric information in the marketplace, and as we have seen in the discussion of U.S. financial crisis episodes, is an important part of the recovery process from a financial crisis. Slow resolution of bankruptcies can therefore delay recovery from a financial crisis because only when bankruptcies have been resolved is there enough information in the financial system to restore it to a healthy operation.

Another important institutional feature of financial systems in many developing countries is the short duration of debt contracts, both domestic and those issued to foreigners. This leads to increased cash flow and liquidity problems for nonfinancial firms and banks when interest rates rise or when the domestic currency depreciates. Having an institutional structure in which debt duration is short thus increases the fragility of the financial system and makes developing countries more prone to financial crises. In order to promote financial stability, developing countries need to encourage the development of longer term debt markets. One way they might do this is by trying to issue longer-term government debt to increase liquidity in markets for long-term debt. ${ }^{27}$ However, one impediment to such a strategy is that financial institutions in developing countries might only be able to finance purchases of these securities in the money market with very short-term liabilities. The resulting maturity mismatch for these institutions can be highly problematic if there are substantial fluctuations in interest rates, a particular problem in developing countries. The resulting market (interest-rate) risk can be substantial and a sharp rise in interest rates which decreases the value of the long-term securities banks hold as assets while having little effect on the value of their short-term liabilities can cause a sharp

\footnotetext{
${ }^{27}$ However, there is one advantage from governments issuing short-term debt: it reduces the incentive for the government to pursue inflationary policies to reduce the real value of their liabilities. Similarly, an advantage to denominating government debt in foreign currency is that there is no longer an incentive to lower the value of the debt by inflation and depreciation of the domestic currency. It is not clear how important these advantages are in practice.
} 
deterioration in bank net worth and lead to insolvencies. Indeed this problem suggests that regulatory requirements or bank supervisory procedures to limit market risk may be especially important in developing countries. The problem of limiting interest-rate risk and encouraging longer duration debt contracts also suggests that it is important for developing countries to pursue the goal of price stability because without price stability there will be substantial fluctuations in interest rates, leading to high interest-rate risk and making it harder to induce private markets to issue long-term debt.

The experience in countries such as Mexico illustrates how dangerous denominating a large amount of debt in foreign currencies can be. Denominating debts in foreign currencies is very tempting for firms, banks and governments in developing countries because instability in the value of the domestic currency makes it harder to attract capital, particularly foreign capital, if the debt is denominated in the domestic currency. However, it is extremely important that this temptation be resisted. Not only does denominating debt in foreign currencies make a developing country's financial system more prone to a financial crisis, but in addition it makes the negative consequences of a financial crisis much more severe. Furthermore, as we have seen, if a financial crisis does occur, a developing country with a lot of its debt denominated in foreign currencies has very limited policy options to extricate itself from the crisis. The dangers of denominating debt in foreign currencies is one of the most important lessons that we learn from the asymmetric information theory of banking and financial crises in developing countries.

The asymmetric information analysis in this paper also illustrates how dangerous a pegged exchange rate regime can be for a developing country if it has a fragile banking system, short duration debt contracts and substantial amounts of debt denominated in foreign currencies. With a pegged exchange rate regime, depreciation of the domestic currency when it occurs is a highly nonlinear event because it involves a devaluation. The resulting dramatic increase in interest rates and rise in indebtedness which results in a sharp deterioration in firms' and banks' balance sheets then tips the developing country into a full scale financial crisis, with devastating effects on the economy. Thus, a pegged exchange rate regime with the institutional features outlined above is like putting the economy on a knife edge. One slip and the economy comes crashing down, and as with Humpty Dumpty, it is very hard to quickly put the economy back together again. The reason that some developing countries have chosen to peg their currency 
to a stable currency like the dollar is because they are seeking a nominal anchor that will promote price stability. However, if they have an institutional structure of a fragile banking system, short duration debt contracts and substantial debt denominated in foreign currencies, this is a very dangerous strategy indeed. ${ }^{28}$

A flexible exchange rate regime has the advantage that movements in the exchange rate are much less nonlinear than in a pegged exchange rate regime. Indeed, the daily fluctuations in the exchange rate in a flexible exchange rate regime have the advantage of making clear to private firms, banks and governments that there is substantial risk involved in issuing liabilities denominated in foreign currencies. Furthermore, a depreciation of the exchange rate may provide an early warning signal to policymakers that their policies may have to be adjusted in order to limit the potential for a financial crisis.

I have already touched on the topic of price stability as a worthy goal. Being a central banker, I cannot resist harping back to a central banker's favorite topic. Central bankers in developed countries are rightfully accused of having a fixation on price stability. I am not going to go into all the reasons why price stability is so desirable and is usually considered to be the primary goal for central banks in developed countries. This is well-covered territory and I will not bore you with it here. The analysis of banking and financial crises here, however, makes it even clearer how imperative the pursuit of price stability is for developing countries. As mentioned above, price stability can help promote financial stability because it leads to longer duration debt contracts. In addition, achieving price stability is a necessary condition for having a sound currency. With a sound currency, it is far easier for banks, nonfinancial firms and the government to raise capital with debt denominated in domestic currency, which reduces financial fragility and reduces the negative impact of a financial crisis on the economy. Price stability also promotes the ability of policymakers to extricate a country from a financial crisis if it occurs.

Furthermore, as we have seen, countries with highly variable inflation, have a credibility problem which limits what policymakers can do to promote recovery from a financial crisis.

\footnotetext{
${ }^{28}$ See Obstfeld and Rogoff (1995) for additional arguments why pegged exchange rate regimes may be undesirable.
} 
Without credibility, a central bank in a developing country that tries to use expansionary monetary policy to enhance the recovery from a financial crisis may do more harm than good. Instead of shoring up weakened balance sheets, the expansionary policy is likely to lead to rapid rises in expected inflation and hence in interest rates as well as an exchange rate depreciation, all of which causes balance sheets to deteriorate further, thus making the financial crisis worse. Similarly engaging in a lender-of-last-resort rescue might backfire because it leads to worries about the commitment to low inflation. With a credible commitment to price stability, this vicious cycle will not occur. Expansionary monetary policy and the lender-of-last-resort role can be effectively used to shore up balance sheets and either nip a financial crisis in the bud or promote rapid recovery when a financial crisis occurs, as examples from U.S. history suggest. The asymmetric information analysis of banking and financial crises in developing countries thus leaves us with the following conclusion: Having an independent central bank with a clear cut mandate for price stability is possibly even more important for developing countries than it is for developed countries.

However, just as with the worthy goal of financial liberalization, single-minded pursuit of price stability can be dangerous. A rapid disinflation process which leads to high real interest rates has adverse cash flow consequences for financial institutions such as banks. If the financial system is very fragile with already weakened balance sheets, the disinflation could result in a major financial crisis, with the resulting depressing effects on the economy. Thus, before engaging in an anti-inflation stabilization program, developing countries need to pay particular attention to the health of their financial system, making sure that the regulatory/supervisory process has been effective in promoting strong balance sheets for financial institutions. Otherwise, financial institutions may not be able to safely weather the stresses from an antiinflation stabilization program. Successful monetary policy in developing countries, therefore, requires successful regulation and prudential supervision of the financial system. 


\section{REFERENCES}

Akerlof, G. (1970). "The Market for Lemons: Quality Uncertainty and the Market Mechanism", Quarterly Journal of Economics, Vol. 84, pp. 488-500.

Bernanke, B.S. (1983). "Non-Monetary Effects of the Financial Crisis in the Propagation of the Great Depression", American Economic Review, Vol. 73, pp. 257-76.

Bernanke, B.S, Gertler M. (1989). "Agency Costs, Collateral, and Business Fluctuations", American Economic Review, Vol. 79, pp. 14-31.

Bernanke, B.S., and Gertler M. (1995). "Inside the Black Box: The Credit Channel of Monetary Policy Transmission," Journal of Economic Perspectives, Fall 1995, 9, pp. 27 48.

Bernanke, B.S. and C. Lown (1991). "The Credit Crunch," Brookings Papers on Economic Activity, 2, pp. 205-39.

Boyd, J. and Gertler, M. (1993). "U.S. Commercial Banking: Trends, Cycles and Policy", NBER Macroeconomics Annual 1993, pp. 319-368.

Brimmer, A.F. (1989). "Distinguished Lecture on Economics in Government: Central Banking and Systemic Risks in Capital Markets", Journal of Economic Perspectives, Vol. 3, pp. 3-16.

Calomiris, C.W. and Gorton, G. (1991). "The Origins of Banking Panics: Models, Facts and Bank Regulation"in Hubbard, R.G. (ed.) Financial Markets and Financial Crises. University of Chicago Press, Chicago, pp. 109-173.

Calomiris, C.W., Hubbard, R.G. (1990). "Firm Heterogeneity, Internal Finance, and 'Credit Rationing'”, Economic Journal, 100, pp. 90-104.

Cecchetti, S.G., (1995). "Distinguishing Theories of the Monetary Transmission Mechanism," Federal Reserve Bank of St. Louis Review, May/June 1995, 77, pp. 83-97.

Diamond, D. (1984). "Financial Intermediation and Delegated Monitoring", Review of Economic Studies, Vol. 51, pp. 393-414.

Drees, Burkhard and Pazarbasioglu, Ceyla (1995). "The Nordic Banking Crises: Pitfalls in Financial Liberalization?" International Monetary Fund Working Paper, WP/95/61, 
June.

Edwards, F. and Mishkin, F.S. (1995). "The Decline of Traditional Banking: Implications for Financial Stability and Regulatory Policy," Federal Reserve Bank of New York Economic Policy Review, July, 1, \#3, pp. 27-45.

Euro-currency Standing Committee of Central Banks of Group of 10 Countries (Fisher Group). (1994), "Discussion paper on "Public Disclosure of Markets and Credit Risks by Financial Intermediaries," September.

Federal Reserve Bank of New York, (1993). "The Role of the Credit Slowdown in the Recent Recession," Federal Reserve Bank of New York Quarterly Review, Spring, 18, $\# 1$.

Federal Reserve Bank of New York, (1994) "A discussion paper "Public Disclosure of Risks Related to Market Activity," September.

Fisher, I. (1933). "The Debt-Deflation Theory of Great Depressions", Econometrica, Vol. 1, pp. $337-57$

Garber, Peter M. and Subir Lall. (1996). "The Role and Operation of Derivative Markets in Foreign Exchange Market Crises," mimeo. February.

Gertler, M. (1988a). "Financial Structure and Aggregate Economic Activity: An Overview", Journal of Money Credit and Banking, Vol. 20, Part 2, pp. 559-88

Gertler, M. (1988b). "Financial Capacity, Reliquification, and Production in an Economy with Long-Term Financial Arrangements", University of Wisconsin, mimeo

Gorton, G. (1988). "Banking Panics and Business Cycles", Oxford Economic Papers Vol. 40, pp. 751-81.

Greenwald, B., Stiglitz, J.E. (1988) "Information, Finance Constraints, and Business Fluctuations", in Kahn, M., and Tsiang, S.C. (eds) Oxford University Press, Oxford. Greenwald, B., Stiglitz, J.E., and Weiss, A. (1984). "Information Imperfections in the Capital Market and Macroeconomic Fluctuations", American Economic Review, Vol. 74, pp. 194-99.

Jaffee, D. and Russell, T. (1976) "Imperfect Information, Uncertainty , and Credit Rationing", Quarterly Journal of Economics, Vol. 90, pp. 651-66.

Kane E.J., The S\&L Insurance Mess: How Did it Happen? Washington, D.C.: Urban 
Institute Press.

Hancock, D., Laing, A.J. and J.A. Wilcox (1995). "Bank Capital Shocks: Dynamic Effects on Securities, Loans and Capital," Joumal of Banking and Finance 19, 3-4: 66177.

Hausman, R. and M. Gavin (1995). "The Roots of Banking Crises: The Macroeconomic Context," Inter-American Development Bank mimeo, October.

Hubbard, R.G. (1995), "Is There a "Credit Channel" for Monetary Policy?", Federal Reserve Bank of St. Louis Review, May/June 1995, 77, 63-74.

Kaminsky, G.L. and C.M. Reinhart (1996). "The Twin Crises: The Causes of Banking and Balance of Payments Problems," Board of Governors of the Federal Reserve System, mimeo. February.

Kydland, F. and E. Prescott (1977). "Rules Rather than Discretion: The Inconsistency of Optimal Plans," Journal of Political Economy 85, pp. 473-91.

Mankiw, N.G. (1986). "The Allocation of Credit and Financial Collapse.", Quarterly Journal of Economics, Vol. 101, pp. 455-70.

Mishkin, F.S. (1991). "Asymmetric Information and Financial Crises: A Histori cal Perspective", in Hubbard, R.G. (ed.) Financial Markets and Financial Crises. University of Chicago Press, Chicago., pp. 69-108.

Mishkin, F.S. (1992). " An Evaluation of the Treasury Plan for Banking Reform. Journal of Economic Perspectives, Vol. 6 (Winter), pp. 133-53.

Mishkin, F.S. (1994). "Preventing Financial Crises: An International Perspective," Manchester School, 62, (1994): 1-40.

Mishkin, F.S. (1995a). The Economics of Money, Banking, and Financial Markets, Fourth Edition. HarperCollins, New York.

Mishkin, F.S. (1996). "The Monetary Transmission Mechanism: Lessons for Policy" mimeo, February.

Mayer, Colin (1990), "Financial Systems, Corporate Finance, and Economic Development," in Hubbard, R.G. (ed.) Asymmetric Information, Corporate Finance, and Investment. Chicago: U. of Chicago Press.

Myers, S.C., and Majluf, N.S. (1984). "Corporate Financing and Investment Decisions 
When Firms Have Information that Investors Do Not Have", Journal of Financial Economics, Vol. 13, pp. 187-221

Obstfeld, M. and K. Rogoff, (1995). "The Mirage of Fixed Exchange Rates," Journal of Economic Perspectives Fall, 9, \#4, pp. 73-96.

Peek, J. and E.S. Rosengren (1995). "Bank Regulation and the Credit Crunch," Journal of Banking and Finance 19, 2-4, pp. 679:92.

Rojas-Suarez, Liliana and Steven R. Weisbrod (1994). "Financial Market Fragilities in Latin America: From Banking Crisis Resollution to Current Policy Challanges," IMF Working Paper WP/94/117, October.

Romer, C. (1992). , "What Ended the Great Depression?" Journal of Economic History, December 1992, 52, \#4, pp. 757-784.

Stiglitz, J.E., and Weiss, A. (1981). "Credit Rationing in Markets with Imperfect Information", American Economic Review, Vol. 71, pp. 393-410.

Stiglitz, J.E., and Weiss, A. (1983). "Incentive Effects of Terminations: Applications to Credit and Labor markets," American Economic Review, Vol. 73, pp. 912-27. 